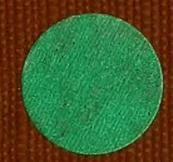




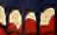

a-

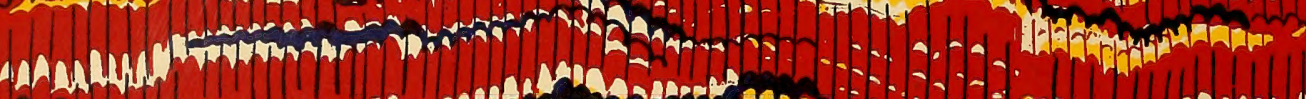

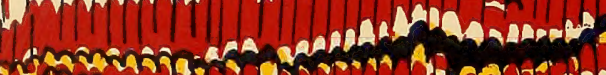

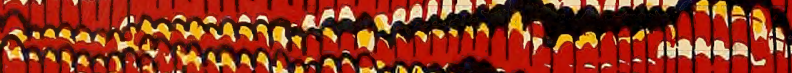

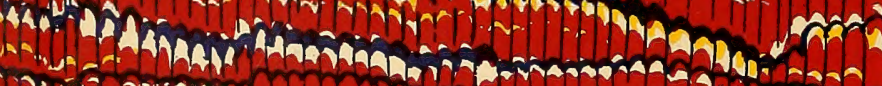

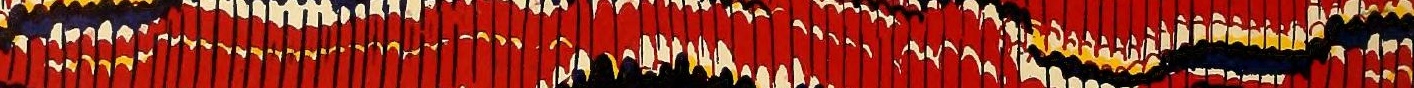

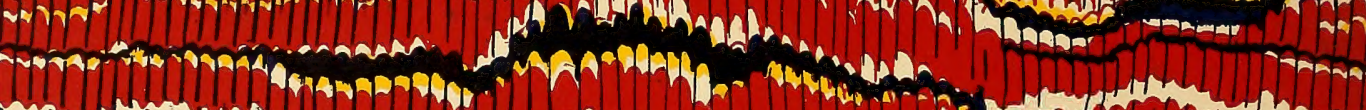

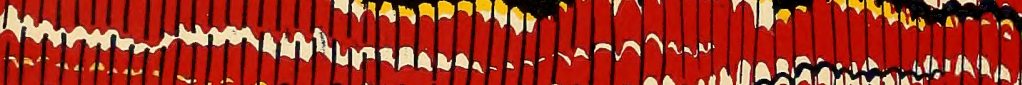
1. $\rightarrow$

$+4$

mimence.

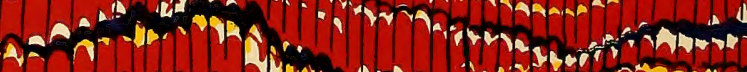
Han -2

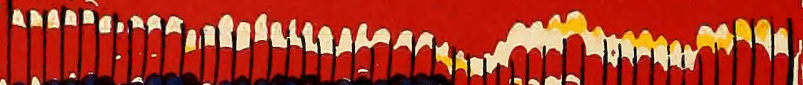
$y$. a. mantim

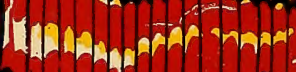

Lenting AH

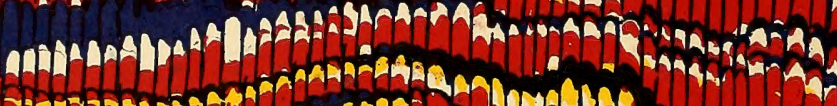

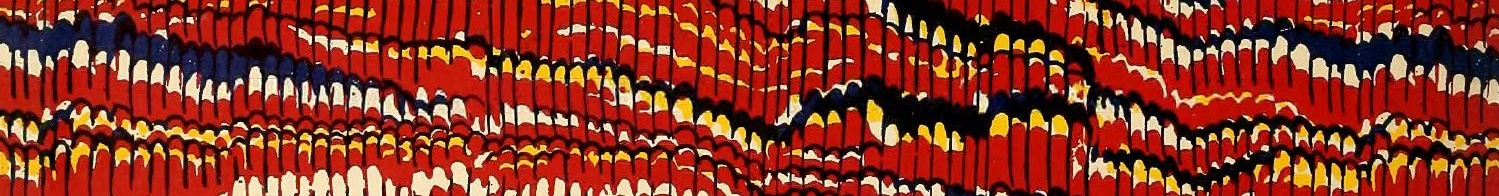

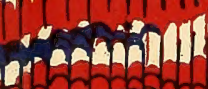

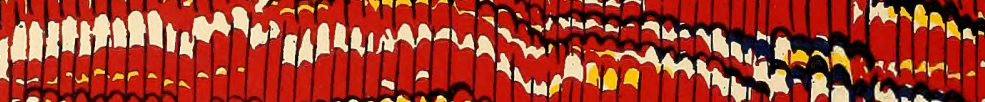$$
\text { - 12- }
$$$$
\text { WAAthath }
$$

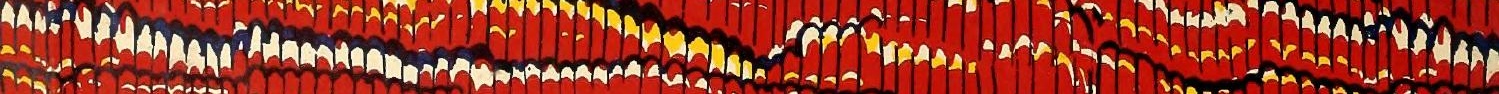

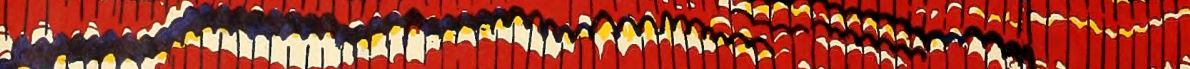
anchanchis

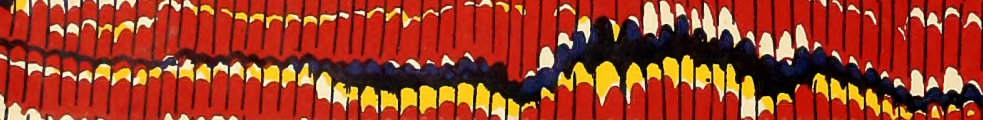

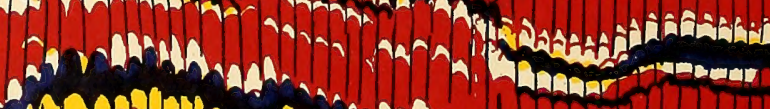
$\operatorname{tin} x$ 





[NoVEMBER, 1891.]

THE

\title{
SCIENTIFIC TRANSACTIONS
}

\author{
OF THE

\section{ROYAL DUBLIN SOCIETY.}

VOLUME IV. (SERIES II.)

XII.

A REVISION OF THE BRITISH ACTINIA. PART II. : THE ZOANTHE丑.

By ALFRED C. HADDON, M.A. (Cantab.), M.R.I.A., Professor of Zoology, Royal College of Science, Dublin; and MISS ALICE M. SHACKLETON, B.A. Plates LVIII., LIX., LX.

\section{U B LIN :}

PUBLISHED BY THE ROYAL DUBLIN SOCIETY. LONDON: WILLIAMS AND NORGATE.

PRINTED AT THE UNIVERSITY PRESS, BY PONSONBY AND WELDRICK, PRINTERS TO THE SOCIETY.

1891. 



\title{
SCIENTIFIC TRANSACTIONS
}

\author{
OF THE

\section{ROYAL DUBLIN SOCIETY.}

VOLUME IV. (SERIES II.)

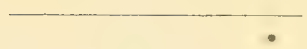

XII.

A REVISION OF THE BRITISH ACTINIAE. PART II. THE ZOANTHE丑. By ALFRED C. HADDON, M.A. (Cantab.), M.R.I.A., Professor of Zoology, Royal College of Science, Dublin; and MISS ALICE M. SHACKLETON, B.A. Plates LVIII., LIX., LX.

\section{8}

\section{U B LIN :}

PUBLISHED BX THE ROYAL DUBLIN SOCIETY.

LONDON: WILLIAMS AND NORGATE.

PRINTED AT THE UNIVERSITY PRESS, BY PONSONBY AND WELDRICK, PRINTERS TO THE SOCHETY. 

XII.

A REVISION OF THE BRITISH ACTINIÆE. PART II.: THE ZOANTHEÆ. By ALFRED C. HADDON, M.A. (Cantab.), M.R.I.A., Professor of Zoology, Royal College of Science, Dublin; and Miss ALICE M. ShackLeTON, B.A. Plates LVIII., LIX., LX.

[Read FeBRUART 18, 1891.]

CONTENTS.

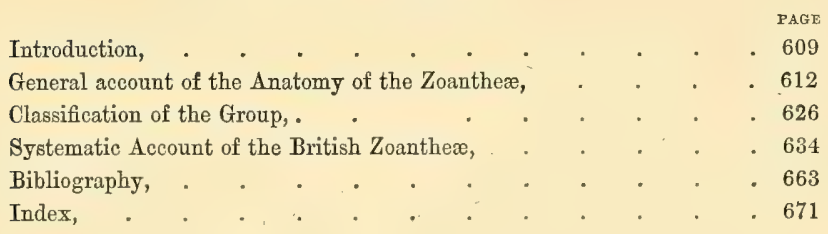

\section{INTRODUCTION.}

THE first part of this Revision dealt with a new sub-family of the Sagartidæ, the Chondractininæ, which included the genera Chondractinia, Hormathia, Chitonactis, Actinauge, and Paraphellia. A few notes were made on the genus Sagartia; and details are given of British representatives of Gephyra dohrnii. The British members of the families Edwardsidæ and Halcampidæ were described; and the nature of Gonactinia prolifera was discussed. An account was also given of the arrangement of the mesenteries in the Zoantheæ. The Paper concluded with a summary of the development of the mesenteries of Actinia; and certain general considerations were advanced on the phylogenetic value of the mesenteries. Unavoidable circumstances caused this first part of the Revision to be heterogeneous in character, and unsatisfactory in many details.

The present instalment of the Revision is confined to a very distinct group of the Actinix. Although there has been considerable confusion within the group, the 
Zoantheæ themselves have, since the time of de Blainville, been recognized as a well-marked division of the Actiniæ.

With the exception of the genus Sphenopus, and certain free varieties of the genus Epizoanthus, all the members of this group are permanently fixed, and with very few exceptions form colonies, the individuals of which are united by the adhering base or cœnenchyme. The cœnenchyme extends laterally, and from it new polyps arise, which remain permanently connected with the colony.

The cœenenchyme may be band-like or form broad encrusting sheets; usually it is thin, but in the genus Palythoa it is so thick that the polyps are more or less immersed within it. The polyps may be placed at considerable intervals from each other, or they may be crowded together, the latter condition being usually due to gemmation from the base of the polyps rather than from the cœnenchyme.

It is characteristic of the group for the body-wall of the polyp and coenenchyme to be incrusted with foreign particles-grains of sand, spicules, foraminifera, and such like. Some genera, such as Palythoa and Sphenopus, are always densely incrusted; the incrustations in Parazoanthus vary according to the species from a considerable amount to very few ; finally, the genera Zoanthus and Mammillifera are unincrusted.

The Zoanthex have the same body-regions as other Actiniæ, with the exception of the basal disc, which must necessarily be absent in the colonial forms, and of a physa in the free forms. In all the column is divisible into scapus and capitulum; the former is usually rigid. In nearly all preserved specimens the capitulum is retracted, and this appears to be generally the case when living, for these forms do not fully expand so frequently as most other sea-anemones. The capitulum is usually thrown into triangular ridges.

The tentacles are bicyclic, and may be very short or moderately long. When fully expanded, the oral dise may be flat or projecting. The mouth is always linear. Only one oesophageal groove is present.

The colours are usually various shades of yellow, buff, and brown, due to the sand incrustations; some have varied colours-pink, green, violet, and so forthbut it is very rare for the colours to be so vivid as is customary among other Actiniæ.

Reproduction takes place by means of ova, by basal and cœenenchymatous gemmation, and by fission.

The foregoing are all the characters which are available for the field naturalist, and, until quite recently, were the only ones on which the definition of species and their systematic arrangement were based. These purely external characters are more than usually unsatisfactory for diagnostic purposes; hence 
the not unnatural confusion into which the group has fallen, and from which it has, to a certain extent, been extricated through the labours of Erdmann and $\mathrm{M}^{\mathrm{e}}$ Murrich. In no group is it more necessary to combine anatomical and microscopical examination with the methods of the older zoologists-for the species of Zoantheæ can only be established after sections have been cut and studied. The identification of new material with recognized species requires the utmost circumspection.

It is impossible to determine the genus to which many previously described species belong until the types have been re-discovered, and then submitted to an anatomical investigation. A complete monograph of the group is at present an impossibility. We have, however, ventured as far as we safely could in this direction.

We have investigated the anatomy of eleven species belonging to five genera of Zoanthex from Torres Straits, besides several other forms, at the same time that we were occupied upon the British representatives. Our Paper on the Torres Straits specimens is published simultaneously with this one, and in the same Journal; and we would ask those who are interested in this group to study both Papers together, for the two are, to a certain extent, complementary to each other.

Methods.-All the specimens examined by us were preserved in alcohol, and when a sufficient quantity of strong alcohol is used this answers perfectly well. We stained the objects whole in borax carmine, imbedded them in paraffin, and cut them with a "rocking" microtome. In a few cases we stained the sections after they were fixed on the slides.

The unincrusted genera are very easy to cut, and so are some of the incrusted forms, especially some of the species of Parazoanthus. Those wishing to study the anatomy of the group cannot do better than commence with $P$. axinellce, which is very easily cut by the ordinary paraffin method. It was perfectly unnecessary for von Koch to employ his "Schliff-methode" (Morph. Jahrb. vi., 1880, p. 359) when investigating this species. We mention this solely to prevent others from taking superfluous trouble. The different species of the genus Epizoanthus are, as a rule, difficult to sectionize, on account of the incrustations. E. paguriphilus is, however, practically free from them; owing to the great thickness of the mesoglœa in this species, celloidin is a better imbedding material than paraffin, as heat has to be employed in the latter method. As a rule, the incrustations in Zoantheæ from coral seas are calcareous, and admit of being readily dissolved away. We use nitric acid for this purpose.

The use which we have made of the Papers of Erdmann and $\mathrm{M}^{\circ}$ Murrich will emphasize the indebtedness of students of the Zoantheæ to those investigators. References to other workers will be duly acknowledged where we 
utilize their results. The laborious monograph of Andres has been in constant requisition.

It is now our pleasing duty to acknowledge the assistance of many friends. The Rev. Canon. A. M. Norman and Professor W. C. M'Intosh have generously placed the whole of their collections at our service; and it is due to the considerable number of foreign (Mediterranean and North Atlantic) specimens belonging to the former that we have been enabled to determine several non-British species. The Director of the Marine Biological Laboratory at Plymouth, and Mr. G. Y. Dixon have also supplied us with specimens, as have also our foreign colleagues, Drs. D. C. Danielssen and J. Playfair $\mathrm{M}^{\mathrm{c}}$ Murrich. Finally, we have to thank Dr. E. Perceval Wright for the loan of books and for ready assistance in the solution of taxonomic and synonymic difficulties.

\section{GENERAL ACCOUNT OF THE ANATOMY OF THE ZOANTHEÆ.}

The main external characters of the Zoantheæ have already been given in the Introduction; and before giving a detailed account of the anatomy of the group it will be necessary to say a few words as to the anatomy of these Actiniæ.

As in other Actinozoa, the body-wall is composed of three layers: the ectoderm, the mesoglœea, and the endoderm. There is now no need to adduce arguments in favour of the employment of the second of these terms.

The mouth leads into a rather short esophagus or stomatodæum, the walls of which are often thrown into folds; at one end a distinct and sometimes a very deep groove is present, for which one of us has suggested the name of "sulcus," or sulear groove. Projecting into the cavity, or cœelenteron of the polyp, from its body-wall, are a number of soft plates which are known as mesenteries; sometimes these are called "sarcosepta," and occasionally they are erroneously spoken of as "septa." The employment of the latter term cannot be too strongly deprecated as leading to confusion with the septa, or calcareous radial partitions of the Madreporaria.

The mesenteries of the Zoantheæ fall under two categories-

(1) The large mesenteries 'which extend from the body-wall to the stomatodæum, and which alone bear mesenterial filaments and gonads. These are the "perfect mesenteries" or "macrosepta" of authors.

(2) The small mesenteries which extend only slightly from the body-wall into the ccelenteron, and which are sterile, and do not bear mesenterial filaments. These are the "imperfect mesenteries" or "microsepta."

As in most Actiniæ a pair of mesenteries occurs at each end of the œsophagus; these are usually spoken of as the "directives," or "directive mesenteries." 
The mesenteries which yield such a valuable aid to classification in the Actinix generally are arranged in this group in a very uniform manner.

In the first part of this revision $(1889$, p. 343), a short account is given of the history of the elucidation of the arrangement of the mesenteries in the Zoantheæ. Since this was written the second part of Hertwig's "Challenger" Report has been published, without, however, adding anything to Erdmann's account. $\mathrm{M}^{\circ}$ Murrich has also written two valuable Papers (1889 and $1889 \mathrm{~A}$ ), but no new type of mesenteric arrangement has been described beyond those first pointed out by Hertwig (1882), and properly described by Erdmann.

It is necessary to have a recognized system of terminology in order to describe the arrangement of the mesenteries in the Actiniæ; and it is advisable to have such a terminology as is applicable to the whole of the Actinozoa. One of us has already (1889) proposed the adoption of certain terms, and the abolition of others which have not a precise meaning-as, for example, such words as "dorsal" and "ventral," these latter were replaced by "sulcular" and "sulcar," respectively. When only one axial ossophageal groove is present, it is usually (? always) the sulcar. In the same Paper attention was called to the value of the order of the appearance of the mesenteries in young Actiniæ, as suggesting the affinities of different groups of sea-anemones. The following diagram illustrates the proposed method of naming the mesenteries and chambers at a stage when twelve mesenteries have made their appearance:-

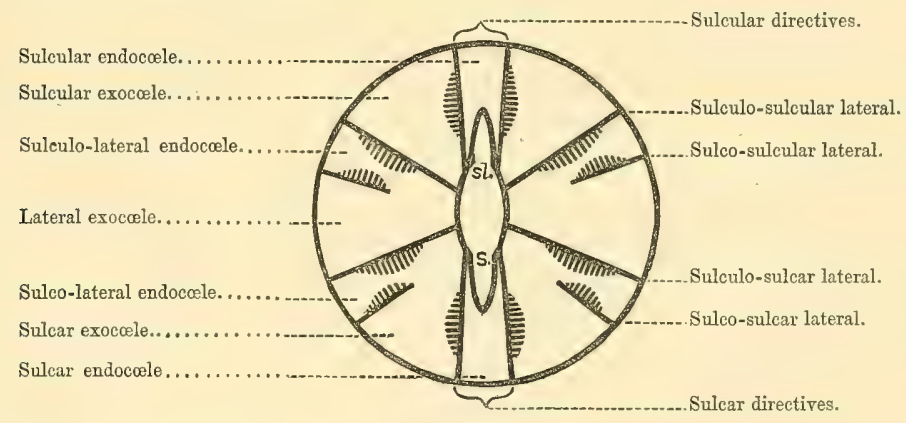

Examples.-Edwardsia has a pair of sulcular and a pair of sulcar directives; a sulculo-sulcular lateral mesentery, and a sulculo-sulcar lateral mesentery on each side, all of which are perfect.

The larval form of Zoanthus has a pair of sulcular imperfect directives and a pair of-sulcar perfect directives; a sulculo-sulcular lateral perfect mesentery, a sulco-sulcular lateral imperfect mesentery, a sulculo-sulcar lateral perfect mesentery, and a sulco-sulcar lateral imperfect mesentery on each side. 
The larval form of Epizoanthus agrees with Zoanthus, except that the sulcosulcar lateral mesenteries are perfect.

In the Zoanther new mesenteries appear in the sulcar exocœles in such a way that the mesenteries nearest the sulcus are the youngest, and those furthest from it the eldest.

In the Sagartidæ the new mesenteries appear in pairs in all the exocœles.

The mesenterial filaments, the gonads, the mesenteric canals, and the cœnenchyme will be dealt with later on. We will now proceed to describe the structure of the Zoantheæ in greater detail in the following order :-

Body-wall-ectoderm, incrustations; mesogloea, cell-enclosures, endodermal bays, ectodermal bays; endoderm, diffuse endodermal muscle, sphincter muscle; capitulum.

Tentacles and Disc.

Essophagus.

Mesenteries.-Imperfect mesenteries, perfect mesenteries, reflected ectoderm and mesenterial filaments, mesoglœa, canals, endoderm, muscles, gonads.

Coonenchyme.

Development.

Parasites.

Body-wall.-Ectoderm.-The ectoderm is very liable to be rubbed off in the incrusted genera; where present it generally appears as a continuous layer of narrow columnar cells. In the unincrusted genera, in Gemmaria macmurrichi and in Epizoanthus paguriphitus, the ectoderm is traversed by strands of mesogloea, which unite to form a layer peripheral to the ectoderm, and which, in some species break up the ectoderm into more or less cubical blocks (Pl. LIx., fig. 6).

External to the ectoderm there is always a cuticular layer which may be very thin, and stains of a darker colour (Parazoanthus dixoni, Pl. LIx., fig. 9), or it may be thick, in which case it rarely stains, and is often impregnated with dirt (Epizoanthus wrightii, Pl. LIx., fig. 3).

As the cuticle is an ectodermal secretion in forms with a continuous ectoderm, and, as the peripheral layer of mesoglœa must also be of ectodermal origin, and is, as a matter of fact, often indistinguishable from the cuticle, we do not consider it of any importance to discriminate between them in the forms with discontinuous ectoderm.

The above-mentioned layer of mesoglœa, peripheral to the ectoderm, is that which is called the subcuticle by Andres (18\%\%, p. 22\%).

The ectoderm usually contains nematocysts, which M'Murrich and others have failed to observe. As a rule these do not stain readily. In some species they are clear; in others-e.g. E. norvegicus (Pl. LIx.; fig. 5), where they are, by-the-by, 
unusually numerous-they contain pigment granules. In E. paguriphitus they are very dark; often they have a yellowish colour, and are somewhat opaque.

Zooxanthellæ are present in the ectoderm of the three species of Isaurus which have been microscopically examined, and in many other species of the Brachycneminæ, but apparently not in all. We have not found them in any of the Macrocneminæ.

Incrustations.-The incrustations which form such a characteristic feature of this group of Actiniæ are absent in the genera Zoanthus and Isaurus, though very rarely a stray spicule, or grain of sand, may be entangled in the cuticlar layer of these genera.

With regard to the other genera, according to our experience, it appears that certain species have a proclivity for a particular kind of incrustation. The character of the incrustation must be conditioned by the precise habitat, i.e. whether sand-grains are calcareous or siliceous, or, again, whether the bottom is sandy or stony; if sponges are abundant on a rocky bottom (as, for example, in Albany Pass, Torres Straits), the forms will probably largely make use of sponge-spicules, as in Parazoantha douglasi. The best example we have of apparent selection is in the case of Epizoanthus incrustatus; of this species we have cut specimens from Norway, Shetland, West of Ireland, and N. E. America (E. americanus, Verrill), and in all cases we find the incrustations to be composed almost entirely of grains of sand. In the single specimen we have been able to examine, of $E$. macintoshi, from Shetland, the incrustations are almost entirely Foraminifera. In Norman's type specimens of Parazoantha anguicoma, from Shetland, the incrustations include grains of sand, Foraminifera, and sponge spicules; this holds good for the same species from the West of Ireland, as well as for the other species ( $P$. dixoni) from the same district.

The amount of incrustation also varies-for example, the species of Epizoanthus are usually thickly incrusted, but in Epizoanthus paguriphilus the incrustations are very few in number. In Parazoanthus dichroicus there are very numerous incrustations, but in $P$. axinelloe they are sparse, and in $P$. dixoni there are still fewer.

Mesogloea.-The mesogloeal ground substance is always homogeneous; it is penetrated by numerous minute cells, which are sometimes star-shaped, but more frequently produced at each end into a long fibril which extends in a radial direction. Some of these fibrils are undoubtedly connected with the ectoderm, and others with the endoderm (PI. LXIv., fig. 1)*; it is impossible to determine whether some may not stretch right across the mesogloea. We have not been able to satisfy ourselves of their presence in every case (ex. E. wrightii).

* Plates LxI. to LxIv. will be found in the Memoir of these Transactions immediately succeeding this one, viz. that on the Zoantheæ of Torres Straits. They are frequently referred to in the present account of the anatomy of the group. 
Cell enclosures.-Large ectodermal canals, penetrating the mesogloea, are very characteristic of the genus Zoanthus; they also occur in Parazoanthus. In $Z$. coppingeri there are numerous large anastomosing canals which arise from the ectoderm (Pl. LxI., fig. 1), and have a general radial direction; many of the canals pass into the mesenteries.

In Isaurus the canals are relatively much smaller than in Zoanthus, and are more broken up than in $Z$. coppingeri, and undoubtedly have an endodermal as well as an ectodermal origin (Pl. LxIII., figs. 5 and 6 ).

The chief feature of the canal system in Parazoanthus is the presence of an encircling sinus, which lies just beneath the endoderm, and extends throughout the whole body-wall. This sinus is not everywhere continuous, but is frequently crossed by bars of mesogloea (Pl. LIx., fig. 8). It is connected with the ectoderm by radial, occasionally branched canals. In $P$. anguicoma and $P$. dixoni, and in some other species, very fine canals connect the sinus with the endoderm (Pl. LIx., fig. 9). Although the encircling sinus may have connexions with the endoderm, these are very delicate, and the sinus itself is undoubtedly of ectodermal origin. The encircling sinus is the same as the "ring-canal" described by Erdmann in his "sp. 8 Palythoa sp." (1885, p. 469). [This is the Palythoa anguicoma of Hertwig, which we believe to be another species, for which we would suggest the name Parazoanthus hertwigi.] Nematocysts are present in the canals of many of the species of Zoanthus and Parazoanthus; possibly they are of universal occurrence in the canals.

In Gemmaria macmurrichi a somewhat similar encircling sinus is present, but it is very largely broken up by the mesogloea into a number of vertical canals which appear in transverse section as a series of lacunæ, each one lying immediately below the union of a mesentery with the body-wall (Pl. LxiII.; fig. 7). These vertical canals are often connected by finer ones.

Lacunæ are found in all the genera of the Zoantheæ except Epizoanthus and Sphenopus. In Zoanthus it appears that the canals are more or less broken up to form the lacunæ, least so in $Z$. coppingeri and $Z$. dance (as identified by Hertwig), and most so in $Z$. jukesii (Pl. LxII., fig. 2), in which species continuous canals are rare; the same also obtains in Isaurus asymmetricus. In Palythoa there are no continuous canals; but lacunæ are present, as these are so similar to those which we know to be of ectodermal origin in other species; and as nematocysts are present, we believe that these lacunæ are of ectodermal origin (Pl. LXIII., figs. 8 and 9).

Small groups of cells, irregularly scattered in the mesogloea, are especially characteristic of the genus Epizoanthus; they may be very numerous, as in E. paguriphilus (Pl. LIx., fig. 6), and in some of the species described by Erdmann, but in other species, E. incrustatus, $E$. couchii, and $E$. wrightii, they are very rare. They 
are abundant in the Parazoanthus dichroicus, and are also common in $P$. anguicoma, and $P$. donglasi. They occur also in Gemmaria macmurrichi, Palythoa hovesii, and P. kochii.

We have no proof that these small and isolated groups of cells, which have been aptly termed "cell-islets" ("Zellinseln") by Erdmann, are connected in any way with the canals or the lacunæ, and, like that investigator, we do not know their origin. We regard these islets as simply groups of ordinary mesogloeal cells.

Endodermal and ectodermal bays.-We may here refer to the endodermal bays described for Isaurus ["Mammillifera"] tuberculatus by $\mathrm{M}^{\circ}$ Murrich (1889, p. 118); he says: "In some of my sections deep bays can be seen running from the endoderm into the mesogloea, and from their ends and sides numerous canaliculi can be seen branching out. These bays can be found in various states of enclosure by the mesogloea, the cells which they contain being in some cases continuous with the general endoderm, in other cases almost separated from it, and finally quite so. So, too, with the ectoderm." We have found similar deep endodermal bays in Isaurus asymmetricus (Pl. Lxiv., fig. 9), but in no case were the bays quite separate from the general endoderm. In our species the ectodermal bays (Pl. LXII., fig. 4) differ considerably from those of $M^{\circ}$ Murrich's species; the latter we have been able to examine through the courtesy of our friend, and as he has not figured one of these bays we add one for comparison (Pl. LXIII., fig. 3).

Endoderm.-The endoderm of the body-wall presents few features worthy of remark. In $I$. asymmetricus we have found nematocysts smaller than those which occur in the ectoderm. Zooxanthellæ are present in the three species of Zoanthus from Torres Straits, and appear to be characteristic of this genus as well as Isaurus. They are also extremely numerous in G. mutuki, and are present in Palythoa howesii and P. kochii. In Parazoanthus dixoni the endoderm is thickened into ridges between the mesenteries, but in most cases it is of uniform thickness.

Diffuse endodermal muscle.-The base of the endoderm forms a feeble but complete muscular sheath; as the fibres run in a horizontal direction, the muscle is scarcely to be seen in transverse sections; in vertical sections (Pl. LIX., figs. 9 and 12) they are readily seen.

Sphincter muscle.-The diffuse endodermal muscle of the general body-wall becomes converted in the capitular region into a sphincter muscle, which in contraction causes the introversion of the corona and capitulum. The genus Parazoanthus is unique amongst the Zoantheæ in possessing an endodermal sphincter. This fact was first discovered by Erdmann (1885, p. 468), who made this a primary character in the definition of his interpretation of the genus Palythoa, of which he took $P$. axinellce as the type. As we shall subsequently explain, Erdmann's genus Palythoa cannot stand; so we have erected the new genus of Parazoanthus in its 
stead. The infoldings of the endodermal sphincter, especially in its upper portion, are frequently so cut across by the razor in sections as to appear isolated, and thus the muscle might be supposed to be partly mesogloal in character (Pl. LX., fig. 8). It is possible that this may actually occur to a very slight extent. In either case the distinction between Zoanther with an endodermal and a mesoglœal sphincter is not so fundamental as might appear at first sight.

All other Zoantheæ have a mesoglœal sphincter. In Sphenopus the sphincter is extremely long, as Erdmann has previously remarked; Zoanthus alone has a double sphincter (P1. LxIv., figs. 3 and 5).

Capitutum.-The capitulum, as all authors have described, is thrown into ridges; these have a certain amount of specific value, but too much reliance should not be placed upon this character.

In all species the ectoderm retains its character as a continuous epithelium. In $Z$. coppingeri the ridges are crowded with nematocysts, but we do not find this of common occurrence.

Tentacles. - The ectoderm of the tentacles contains numerous sausage-shaped nematocysts. The deeper layer of the ectoderm usually exhibits a well-marked nervous layer, the nerve-cells of which are shown in Pl. LxIv., fig. 2. There is a diffuse ectodermal muscular sheath, the fibres of which have a longitudinal direction.

The mesoglœa is usually thin. The endoderm is relatively thick; and in $Z$. coppingeri, Z. jukesii, and $Z$. macgillivrayi zooxanthellæ are here especially abundant, but in $I$. asymmetricus and in Palythoa howesii and $P$. kochii, although they are present in the endoderm of the body-wall, few, if any, are to be found in this region. In $Z$. coppingeri numerous nematocysts of oval shape, similar to those found in the ectoderm of the body-wall, are present in the endoderm of the tentacles (Pl. LxIV., fig. 2). And in some of our specimens of E. couchii similar nematocysts are to be found in the ectoderm of the tentacles. A diffuse endodermal muscular layer consisting of fibres which run in a circular or horizontal direction, and which may be regarded as an extension of the muscular layer of the body-wall, is found in the tentacles of all our species.

Dise.-The structure of the dise is usually similar to that of the tentacles. As in the latter, there are no incrustations.

Esophagus. - The ectoderm of the csophagus is usually more or less folded; but as the degree of folding is variable in different individuals of the same species, and probably also in the same individual in different conditions of contraction, this character is of little value for systematic purposes. The same may be said of the nature and extent of the groove. A sulcar groove is always present, but it is scarcely discernible in our specimens of $I$. asymmetivicus, and in one of the specimens of $E$. incrustatus (Pl. LX., fig. 1). In other specimens of the latter species it is, 
however, distinct. Nematocysts are found in the ectoderm of the osophagus of Palythoa coesia (?), E. couchii, and E. arenaceus.

The mesogloea of the eesophagus is generally thin, but in many species of Epizoanthus and of Parazoanthus it is much thickened in the groove. Cell enclosures are generally absent in this region, but we have seen a few cell-islets in the mesogloea of the groove of $P$. anguicoma (one specimen), and they are also present in that of $P$. dichroicus.

Mesenteries.-The mesenteries which are such a valuable aid to classification of the Actiniæ generally are arranged in this group in a very uniform manner, which we have already described.

Imperfect mesenteries.-The imperfect mesenteries vary in the extent to which they project into the colenteron. In E. incrustatus, and in Parazoanthus douglasi they are very small, whereas in $P$. dixoni they are well developed. When canals are present in the perfect mesenteries they are also to be found in the imperfect.

Perfect mesenteries.-There is no distinction between any of the perfect mesenteries.

Ectoderm. - The presence of ectoderm in certain mesenteries of the Anthozoa appears to be now fairly well established. E. B. Wilson ("Mesenterial Filaments of the Alcyonaria": Mitth. Zool, Stat. Neapel, v. 1884) came to the conclusion that the "dorsal" pair of filaments in the Alcyonaria were ectodermal in origin, but that the other six filaments were solely endodermal; these two kinds of filaments can be readily distinguished histologically. Some years previously von Heider (Cerianthus membranaceus, Haime: Sitz. kais. Acad. Wien, Ixxix. 1879) believed, solely from a histological study of the adult Cerianthus, that the filaments of that form were ectodermal. The Brothers Hertwig (Die Actinien, 1879) pointed out that embryological deductions based on adult histology were not very reliable, and also brought forward, as an objection to von Heider's view, the existence of filaments on imperfect mesenteries in the Actiniæ generally. H. V. Wilson (Journ. Morph. II., 1888) has shown for the coral Manicina, and J. P. $\mathrm{M}^{\mathrm{c}}$ Murrich (ibid. Iv. 1891) for the Actinian, Rhodactis, that the mesenterial filaments are derived from the ectoderm of the osophagus.

From the histological characters and absolute continuity of what we have termed the "reflected ectoderm" of the mesenteries with the ectoderm of the œsophagus on the one hand, and with the mesenterial filament (craspedum) on the other, we have no doubt as to the morphological identity of these tissues.

Reflected Ectoderm and Filaments. - The mesenteric ectoderm consists of two portions, an upper, which we speak of as the "reflected ectoderm," and a lower portion, which runs down the edge of the mesentery, and is known as the mesenterial filament, or "craspedum" of Gosse. These two are perfectly continuous with each other and with the ectoderm of the œsophagus. 
In looking at a side view of a mesentery such as that of $Z$. macgillivrayi (Pl. LXIV., fig. 5) it will be seen that the ectoderm of the œsophagus passes continuously on to the mesentery where it suddenly becomes greatly thickened, and is thrown into transverse folds ; the whole thickening has a crescentic form, first coming upwards and then downwards losing itself in the mesenterial filament. The ectoderm is reflected on both sides of every one of the perfect mesenteries (Pl. LX., fig. 6), and presents a very characteristic appearance in transverse sections (PI. LxIv., figs. 4 and 6). The folds often present a pinnate appearance, but they are rarely accurately symmetrical on each side.

In some species the endoderm is implicated in the upward reflection of the lower edge of the œsophagus; this is especially noticeable in Parazoanthus axinellce (Pl. LX., fig. 6), but it is not a feature of any morphological importance.

As above mentioned the refiected ectoderm passes gradually into the mesenterial filament. The characteristic trefoil ( $P$. axinellce) (Pl. Lx., fig. 6) or $\mathrm{V}$-shape (Z. macgillivrayi) (Pl. LXIv., fig. 7) of the latter in transverse sections is continuous with the peripheral pair of folds of the reflected ectoderm.

The lateral elements of the upper portion of the craspedum gradually become shorter, so that eventually only the median portion is left (PI. Lx., fig. 7). This transition takes place very shortly below the lower level of the œesophagus.

Nematocysts are numerous in the simple lower portion of the mesenterial filament; but they are not readily seen in the upper portion, and we have not observed any in the reflected ectoderm. Unicellular glands and pigment granules also occur in the filament.

The length of the craspeda varies even in the same genus, it apparently being dependent upon the height of the polyp; for example in $Z$. jukesii, which is a short species, the filaments extend nearly down to the commencement of the cœenenchyme, whereas in $Z$. macgillivrayi they cease about half way down the polyp.

Mesogloea.-The mesoglœa of the mesenteries exhibits a certain amount of variation in thickness; for example, in the œsophageal region of Parazoanthus dixoni (Pl. Lx., fig. 9), the mesogloea is relatively thick, whereas in Epizoanthus paguriphilus ( $\mathrm{Pl}$. Lx., fig. 5) it is quite thin.

Canals.-In describing the canals in the mesoglœa of the body-wall, we have already alluded to the fact that in the three species of the genus Zoanthus from Torres Straits which we have examined, they not only arise from the ectoderm, but pass into the mesenteries.

Hertwig (1882, p. 115) describes in $Z$. dance (?) (cf. 1888, p. 36) a basal "septal canal" "in the supporting lamella of the septa in immediate proximity to the wall." He "never could make out any connexion between this septal canal and the ectodermal cords $[i$. e. canal system $]$ of the wall"; and he is 
"inclined to believe that it is produced from the enduderm." His reason is that the zooxanthellæ, which are found in the mesenteric canal of this species, "force their way into the septal canal, but never into the canals of the wall." According to our experience there are no connexions between the canal-system of the body-wall and the mesenteric canals in the oesophageal region of the body, although they are numerous lower down. The section Hertwig figures is from the oesophageal region.

$M^{\circ}$ Murrich ( $1889 \mathrm{~A}$, p. 64) finds in $Z$. sociatus, in "one mesentery, the basal canal communicating with one of the spaces in the mesogloea of the column wall." He adds: "It seems open to question whether the cells of the larger cavities in the mesoglœa are not in reality endodermal in their origin." In his subsequently written, but previously published Paper (1889, p. 114), in alluding to the body-wall canals of $Z$. flos-marinus, he refers the reader to his description of Isaurus ["Mammillifera"] tuberculatus for his views as to the origin of these canals, evidently believing that the "endodermal bays" of the latter species give rise to some of the canals, the remainder being similarly derived from the ectodermal bays, and then not unnaturally concludes that the mesenteric canals are connected only with the endodermal "spaces" of the body-wall. We have corroborated M'Murrich's observation as to the double origin of the canal-system in the body-wall of Isaurus; but we have no reason for supposing that the canals in the mesenteries are without exception of endodermal origin, although some undoubtedly are (Pl. LxiIr., fig. 5). Our experience leads us to the conclusion that it is necessary to be cautious in arguing as to the origin of these canals from one genus to another. For confirmation of our view, that the mesenteric canals of Zoanthus are of ectodermal origin, we point to the demonstration of this fact for Z. coppingeri (Pl. LXII., fig. 1).

In Z. coppingeri the canals form at the base of each mesentery a large sinus, which extends up the mesentery, nearly to the generative region, where it rapidly narrows, and extends right up the mesentery as the "basal canal." In $Z$. jukesii and in $Z$. macgillivrayi the mesenteric canals are present, though not forming extensive sinuses (Pl. LxII., fig. 2).

In $I$. asymmetricus the canal system appears in sections as if broken up into lacunæ; but it may really form a continuous system of anastomosing canals.

In Gemmaria rusei (1889, p. 125) and G. isolata (1889 A, p. 66) the mesenteric canal, according to $\mathrm{M}^{\mathrm{c}}$ Murrich, has the character of a basal canal. We find the same in our two species. Sinuses, extending throughout the whole length of the mesenteries, occur in the three species of Palythoa we have examined. So far as our experience goes canals are absent from the mesenteries of Epizoanthus, and the same obtains for all the species of Parazoanthus except $P$. anguicoma and $P$. dixoni, in which species we have found sinuses in the bases of the mesenteries which have a slight vertical extension, 
In Parazoanthus dichroicus cell-islets occur in the mesogloea of the mesenteries, and also in E. paguriphilus.

Nematocysts are sometimes present in the canals and sinuses of the mesenteries (e.g. Z. coppingeri (PI. LXII., fig. 1) and Palythoa howesii); but zooxanthellæ are rarely present. We have found them in Palythoa kochii.

Endoderm.-'The endoderm of the proximal portion of the mesenteries usually resembles that of the body-wall, except that it more frequently contains nematocysts, as in $Z$. coppingeri, $Z$. macgillivrayi, and $I$. asymmetricus. In the latter species they are much smaller than those of the ectoderm of the body-wall. Zooxanthellæ occur in the endoderm of the mesenteries in those species in which they are present in the general endoderm.

$M^{c}$ Murrich has carefully described the swollen distal portion of the endoderm of the mesenteries of $Z$. flos-marinus (1889, p. 115, Pl. vii., fig. 4) in that region of the body where the mesenterial filament is simple. We have found a similar enlargement in Z. macgillivrayi (Pl. LXIV., fig. 8), in which nematocysts are present. Our specimen differs from his chiefly in the possession of zooxanthellæ and nematocysts; we have not observed in our species that these endodermal cells are "loaded with green granules, closely packed together."

A similar swelling occurs, to a variable extent, in other species; for example, in P. axinellce (Pl. Lx., fig. 7) it is only moderately developed, and we have not observed nematocysts or zooxanthellæ; but these appear to be absent in the general endoderm of this species. Sometimes the swelling is absent, as in $E$. incrustatus.

We, too, have found, with $M^{c}$ Murrich, "foreign bodies of organic nature imbedded in the cells, sometimes being surrounded by a number of cells containing no granules, or occasionally imbedded in the mesoglœa" (1889, p. 116). He suggests that these are concerned with digestion (Pl. Lxiv., fig. 8).

Muscles. - The muscles of the mesenteries are endodermal and diffuse. As in other Actiniæ there are two kinds of muscles, the longitudinal and the parietobasilar.

The longitudinal muscle is often very difficult to distinguish in transverse section, being feebly developed, and forming a simple layer of fibres (Pl. LXIv., fig. 8). In I. asymmetricus and E. paguriphilus, Parazoanthus dixoni, and others, the muscle is better developed, and is slightly plaited (Pl. Lx., fig. 9).

The parieto-basilar muscle is usually relatively broader, and extends higher up the mesenteries than in other Actinix; but in Parazoanthus anguicoma and P. dixoni, this muscle is very feebly developed, and only occurs at the insertion of the mesenteries (Pl. Lx., fig. 9).

It has been recognized by other investigators that judging by the arrangement of the muscles the mesenteries of the Zoanther are paired, although the 
two elements of each pair are respectively a perfect and imperfect mesentery, and are independently developed. Recently, however, Danielssen (1890) has thrown doubt upon this paired arrangement, since he finds in the various species he has examined that the muscles are, equally dereloped on both sides of the perfect mesenteries. Owing to the kindness of our Norwegian colleague we have been enabled to exarnine some specimens of Epizoanthus ["Mardoell"] erdmanni, and our sections show this paired arrangement quite clearly.

Gonads.-There appears to be a general impression that all the Zoantheæ are hermaphrodite. This is certainly not the case in four genera; of one genus we have no facts either way, and in the the remaining two genera the sexes may be distinct or united. Generative organs often appear to be absent in specimens of Zoanthex, but we have been somewhat fortunate in finding them in those we have examined. Their mode of occurrence will be seen on reference to the Plates in this and in the Memoir on the Zoantheæ from Torres Straits.

Erdmann found that the two species of Zoanthus which he examined (" $1 \mathrm{sp}$. Zoanthus sp. ?," p. 438 (=Z. dance [?], Hertwig); and "2 sp. Z. sp. ?," p. 447) were hermaphrodite, so he concluded that this was a generic character. $M^{\circ}$ Murrich found no generative organs in the two species he examined. Of the three species we have examned, two specimens of $Z$. coppinger $i$ were male and three were female; two specimens of $Z$. jukesii were female, and of the four specimens of $Z$. macgillivrayi we sectionized none were fertile. The conclusion we arrive at is that the genus is as often diœcious as monœcious.

M"Murrich found that Isaurus ["Mammillifera"] tuberculatus was hermaphrodite, and owing to his courtesy we have been enabled to verify this fact. We have cut several specimens of our $I$. asymmetricus, but in only one of them could we discover generative organs, and in this case they were feebly developed ova. We cannot, however, assume that the genus is hermaphrodite because one species is undoubtedly monœcious.

All the remaining genera, so far as is known, are diceious, except Sphenopus, the gonads of which are unknown.

Neither Erdmann nor $\mathrm{M}^{\circ} \mathrm{M}$ urrich found generative organs in the five species of Palythoa " Corticifera") examined by them. We have been more fortunate, since in $P$. kochii we found male organs alone, and in $P$. howesii we found only female.

According to our experience all the members of a single colony of dicecious Zoantheæ belong to the same sex; but we cannot lay down any general rule on this point.

Conenchyme.-The structure of the cœnenchyme is similar in every respect to that of the polyps. The only difference consists in the presence of cœlenteric canals, which are merely prolongations of the cœlenteron of the polyps. 
The cœnenchyme may occur as stolons, more or less riband-like, or as flattened expansions, or, as in Palythoa, it may fill up the intervals between the polyps. Some zoologists have laid stress on the systematic value of the habit of growth of the cœnenchyme; but, as a matter of fact, we have often found that in the same species it varies according to the surface to which the colony is attached, and therefore cannot lay great stress on this character. The genus Gemmaria, as defined by $M^{\circ}$ Murrich, precisely resembles Palythoa (his Corticifera), with the exception of the character of the cœnenchyme, it being absent or lamellar in the former. We consider this a legitimate use of the character of the cœnenchyme for taxonomic purposes.

The most interesting varieties of cœenenchyme occur amongst those species of Epizoanthus which incrust Gasteropod shells inhabited by hermit crabs. In these cases the cœnenchyme dissolves the lime of the shells, which it replaces by its own substance; and thus the carcinæcium practically forms an isomorph of the shell. The spire of the shell is the last portion to be absorbed. In describing the manner in which the polyps are arranged on the cœnenchyme, we employ the terms "dorsal," "ventral," "anterior," "posterior," "right," and "left;" these have reference solely to the position of the carcinæcium with regard to the crab when walling.

Development.-We have no account of the development of any Zoanthean, with the possible exception of an observation by Van Beneden (1890), who describes the anatomy of a larval Actinozoon allied to Semper's larva (Zeitschr. f. wiss Zool., xvii. 1867). He regards it as a larva of a "microtypal" (brachycnemic) Zoanthean, on account of the arrangement of the mesenteries. He adds: "What further confirms our opinion, that our larva and that of Semper may be connected with the development of the Zoantheæ, is that the constitution of the mesenchymatous lamella is particularly well developed, and provided with numerous cellular elements, of which some have an endodermic origin, the others being derived from the ectoderm" (p. 95). The senior author has very recently (Proc. Roy. Dub. Soc. (N. S.), vol. vii., pt. III., p. 127, 1891) published a small Paper on a larval stage of the coral Euphyllia, which presents many of the anatomical peculiarities which characterise Van Beneden's larva; it is only fair to add that in the newly-hatched larva of Euphyllia the mesogloea is thin and without cellenclosures.**

Parasites.-Some of our specimens of Parazoanthus douglasi from Albany Pass are infested by a Copepod which deposits its egg-capsule in the cœlenteron or

* Since the above was in type we have received, through the courtesy of the author, a valuable Paper on "The Phylogeny of the Actinozoa," by Professor McMurrich (1891), in which he gives an account, and four figures (Pl. IX., figs. 5-8), of two stages in the development of a brachycnemic Zoanthean. We regret we can do no more than draw attention to this Paper. 
colenteric canals of the Zoanthean. The capsules are paired, and contain a large number of ova. We have these in the nauplius stage, and in other stages of development. We have two specimens of the Copepod, but are unable to say whether these are adult or not. The capsules form distinct swellings (Pl. LXI., figs. 19-22) of the body-wall of the Actinian. This fact leads us to suppose that the Copepod remains within the colenteric cavities while the capsule is developing; and when the latter is ripe it breaks away from it.

We have sections of a Crustacean in the cœlenteron of the only specimen of Epizoanthus macintoshi (from Shetland) we were able to cut, but we cannot say anything more about it.

Small, oval, deeply pigmented bodies occur in many parts of the body in Parazoonthus dichroicus and in $P$. donglasi (Pl. LXII., figs. 5 and 6). They are evidently parasites, but we have been unable to determine their nature.

Problematical rounded bodies, which stain deeply and uniformly with carmine, are present in $Z$. macgillivrayi, Palythoa howesii, and other species. 


\section{CLASBIFICATION OF THE GROUP.}

\section{ZOANTHE正.}

Actinix with numerous perfect and imperfect mesenteries, and two pairs of directive mesenteries, of which the sulcar are perfect and the sulcular are imperfect. A pair of mesenteries occur on each side of the sulcular directives, of which the sulcular moiety is perfect and its sulcar complement is imperfect; a similar second pair occurs in one section of the group (Brachycneminæ), or the second pair may be composed of two perfect mesenteries (Macrocneminæ). In the remaining pairs of mesenteries, of both divisions, this order is reversed, so that the perfect mesentery is sulcar and the imperfect is sulcular. The latter series of mesenteries are bilateral as regards the polyp and arise independently $(i . e$. neither in pairs nor symmetrically on each side) in the exocœle on each side of the sulcar directives, in such a manner that the sulcular are the oldest and the sulcar the youngest. Only the perfect mesenteries are fertile or bear mesenterial filaments. A single sulcar œsophageal groove is present. The mesoglœa of the body-wall is traversed by irregularly branching ectodermal canals or by scattered groups of cells. The body-wall is usually incrusted with foreign particles. The polyps are generally grouped in colonies connected by a cœnenchyme, the cœlenteron of each polyp communicating with that of the other members of the colony by means of basal endodermal canals.

\section{Family. Z OAN THID Æ, Dana, 1846.}

(With the definition of the group.)

$$
\text { Sub-family. BrachyCNeMin } \approx, \text { n. s.-f.* }
$$

Zoantheæ in which the sulcar element of the primitive sulco-lateral pair of mesenteries (cnemes) is imperfect :-

\section{GENERA AND TYPE SPECIES.}

\begin{tabular}{|c|c|c|}
\hline ZOANTHUS, & Lamarck. & Type Z. sociatus (Ellis). \\
\hline ISAURUS, & Gray. & , I. tuberculatus, Gray. \\
\hline (? MAMMLLLIFERA, & Lesueur. & M. auricula, Lesueur.) \\
\hline Gemmaria, & Duchassaing et Michelotti. & G. rusei, Duch. and Mich. \\
\hline Palythoa, & Lamouroux. & "P. mammillosa(Ellis and Sol.). \\
\hline Sphenopus, & Steenstrup. & "S. marsupialis, Steenstr. \\
\hline
\end{tabular}




\section{Sub-family. Macrocnemin $\approx$, n. s.-f.*}

Zoantheæ in which the sulcar element of the primitive sulco-lateral pair of mesenteries (cnemes) is perfect :-

\section{GENERA AND TYPE SPECIES.}
Epizonnthus, Gray. Parazoanthus, n. g.
Type $E$. incrustatus (Düb. and Kor.).
"P. axinellae (Schmidt).

The Zoantheæ constitute a very well-marked division of the Actiniæ; no connecting forms between these and any other group are known.

The classification of the Zoantheæ proposed by Erdmann has been adopted by all subsequent writers; and as his was the first which was based on internal anatomy, we need not enter into a discussion of the earlier systems.

Erdmann adopts Andres' two families, the Zoanthidæ and the Sphenopidæ, with the following definitions :- "Zoanthidæ: Zoantheen, welche durch ein Coenenchym zu Colonien vereinigt werden;" and "Sphenopidæ: Einzellebende Zoantheen, welche mit ihren abgerundeten Körperende im Sande stecken oder mit einer Art Haftscheibe am Boden festsitzen." It is strange that these families should be based solely upon the habit of growth. In the second family he places Sphenopus and his "genus novum"; the latter is undoubtedly the free (or Sidisia) variety of an Epizoanthus. It is very probable that this is really the free-variety of the type species of Epizoanthus (E. incrustatus). As this form passes out of the family we see no reason for retaining a family for Sphenopus, especially as an isolated mode of growth occurs in the other family, as $\mathrm{MI}^{\mathrm{c}}$ Murrich has shown that Gemmaria rusei is "solitary, being attached to pebbles without the development of any cœnenchyme" (1889, p. 124), and the individuals of his G. isolato" were scattered and buried up to the tentacles in the sand" $(1889 \mathrm{~A}, \mathrm{p} .65)$; and it is characteristic of the genus Isaurus for the polyps to be either solitary, or in small groups with a feeble cœnenchyme. We therefore think it preferable to base divisional characters on anatomical differences.

M ${ }^{\circ}$ Murrich has adopted Andres' three divisions, the third being the Bergidx. As nothing is known about the structure of the latter we think it better to omit them altogether.

success. The objection to the word "cneme" is that it has reference to the appearance of a transverse section of an Actinian rather than to a mesentery as it actually exists. As the investigation of the Zoantheæ, at least, must principally be made by means of transverse sections, this objection has not much weight.

- Ibid. 
We acknowledge only one family in the group which we divide into two sub-families, the Brachycneminæ, and the Macrocneminæ, which are based upon the two well-known types of mesenterial arrangement. It is worthy of notice that, so far as our knowledge at present extends, the Macrocneminæ alone are represented in the North Atlantic, although they are world-wide in distribution.

The following. Table shows the chief generic distinctions at a glance, and demonstrates that the group is a very homogeneous one. We regard Parazoanthus as being the least specialised genus on account of its having a single endodermal sphincter muscle, and Zoanthus as the most specialised, as it possesses a double mesogloeal sphincter muscle. We omit Mammillifera, as the type species have never been described from an anatomical point of view :-

\begin{tabular}{|c|c|c|c|c|}
\hline Genus. & $\begin{array}{l}\text { Mesenterial arrange- } \\
\text { ment. }\end{array}$ & Sphincter. & Gonads. & Body-wall and Coønenchyme. \\
\hline Zoanthus. & Brachyenemic. & Double mesoglœal. & $\stackrel{x}{+}$ or $\pi, q$ & $\left\{\begin{array}{l}\text { Unincrusted; well-deve- } \\
\text { loped ectodermal canal } \\
\text { system. }\end{array}\right.$ \\
\hline Isaurus. & Brachyenemic. & Single mesoglœal. & $\underset{+}{t}$ or $\delta, q$ & $\left\{\begin{array}{l}\text { Unincrusted; ectodermal } \\
\text { and endodermal bays } \\
\text { and small canals; some- } \\
\text { times solitary. }\end{array}\right.$ \\
\hline Gemmaria. & Brachỵenemic. & Single mesoglcal. & ๘, & $\left\{\begin{array}{c}\text { Incrusted; lacunæ; often } \\
\text { solitary, always attached. }\end{array}\right.$ \\
\hline Palythoa. & Brachycnemic. & Single mesoglœal. & d, $q$ & $\left\{\begin{array}{c}\text { Similar to above, but } \\
\text { polyps immersed in } \\
\text { expanded conenchyme. }\end{array}\right.$ \\
\hline Sphenopus. & Brachyenemic. & Single mesoglœal. & $?$ & $\left\{\begin{array}{c}\text { Incrusted; cell-islets; al- } \\
\text { ways solitary and free. }\end{array}\right.$ \\
\hline Epizoanthus. & Macrocnemic. & Single mesoglœal. & $\pi$, 우 & Incrusted; cell-islets. \\
\hline Parazoanthus. & Macrocnemic. & Endodermal. & s, & $\left\{\begin{array}{l}\text { Incrusted ; ectodermal } \\
\text { canals ; cell-islets; en. } \\
\text { circling sinus; ectoderm } \\
\text { always continuous. }\end{array}\right.$ \\
\hline
\end{tabular}


In the following list we have enumerated immediately after the generic description all the species which can be definitely referred to any species, adding in brackets [ ] the initials of the zoologists who have investigated those forms, and on whose authority the generic allocations are made. The initials are as follows:-A., Andres; E., Erdmann; E. \& H., Erdmann and Hertwig, for those species described in the Supplement to Hertwig's "Challenger" Report, 1888, the anatomical work on the Zoanthere being done by Erdmann; H., Hertwig (1882); H. \& S., Haddon and Shackleton; M., MMurrich. Although other zoologists have made anatomical investigations on some forms, yet in no other case is there sufficient information given to enable one to determine the generic position of a particular species.

In a few instances we have added those species which we think may safely be regarded as probably belonging to a particular genus, e.g. Palythoa and those species of Epizoanthus which form carcinæcia, owing to their having a similar habit of growth to species whose genus is known. Beyond this we have not dared to go, as enough confusion has been made in the group without our gratuitously adding to it.

\section{Family. ZOANTHID正. \\ Sub-family. BRACH Y N EMIN 王. \\ ZOANTHUS, Lamarck, 1801.}

Brachycnemic Zoantheæ, with a double mesogloal sphincter muscle. The body-wall is unincrusted; the ectoderm is usually discontinuous; well-developed ectodermal canal system in the mesoglœa. Monœcious or diœcious. Polyps connected by thin cœnenchyme.

\section{RECOGNIZED SPECIES.}

Z. sociatus (Ellis), 1767.-Dominica, Barbadoes, Guadeloupe, Bahamas, [M.].

Z. flos-marinus, Duch. \& Mich., 1860.-St. Thomas, Bermudas, [M.].

Z. dance (?), of Hertw., 1888.-Bermudas (? if the same as Z. danai, Le Conte, 1851, Panama), [E. \& H.].

Z. confertus, of Hertw., 1888.-Cape of Good Hope (? if the same as M. conferta, Verrill, 1868, San Salvador, Acapulco), [E. \& H.].

Z. coppingeri, Hadd. \& Shackl., 1891.-Torres Straits, [H. \& S.].

Z. jukesii, Hadd. \& Shackl., 1891.-Torres Straits, [H. \& S.].

Z. macgillivrayi, Hadd. \& Shackl., 1891.-Torres Straits, [H.\& S.].

Z.sp. (?), Hertw., 1882.-Bermudas, [H.]. 
ISAURUS, Gray, 1828.

Large brachycnemic Zoantheæ, with a single mesoglœal sphincter muscle. The body-wall is unincrusted; the ectoderm is discontinuous; ectodermal and endodermal bays and small canals in the mesoglœa. Monœcious or diœcious. Polyps in small clusters or solitary.

\section{RECOGNIZED SPECIES.}

I. tuberculatus, Gray, 1828.-Guadeloupe, Bermudas, [M.].

I. spongiosus (Andres), 1877.-Port Natal, [A.].

1. asymmetricus, Hadd. \& Shackl., 1891.-Torres Straits, [H. \& S.].

PROBABLY BELONGING TO THIS GENUS.

I. cliftoni (Gray), 1867.-W. Australia.

[? Mammillifera, ${ }^{*}$ Lesueur, 1817.

M. auricula, Lesueur, 1817.-St. Vincent; Dominica.

M. nymphoea, Lesueur, 1817.-St. Christopher.]

GEMIMARIA, Duchassaing et Michelotti, 1860.

Solitary brachycnemic Zoantheæ, with a single sphincter mesoglœal muscle. The body-wall is incrusted with particles of sand. The ectoderm is usually discontinuous, but may be continuous. Lacunæ and cell-islets are found in the mesoglœa. Diœcious.

\section{RECOGNIZED SPECIES.}

G. rusei, Duch. \& Mich., 1860.-St. Thomas, Bermudas, [M.].

G. isolata, M'Murr., 1889.-Bahamas, [M.].

G. macmurrichi, Hadd. \& Shackl., 1891.-Torres Straits, [H. \& S.].

G. mutuki, Hadd. \& Shackl., 1891.-Torres Straits, [H. \& S.].

PROBABLY BELONGING TO THIS GENUS.

G. philippinensis (Gray), 1867.-Philippines.

* The position of this genus cannot be settled until the type species have been recovered and sectionized. 
PALYTHOA, Lamouroux, 1816.

Brachycnemic Zoantheæ, with a single mesoglœal sphincter muscle. The bodywall is incrusted; the mesoglœa contains numerous lacunæ, and occasionally canals. Diocious. Polyps immersed in a thick cœnenchyme.

\section{RECOGNIZED SPECIES.}

P. mammillosa (Ellis \& Sol.), 1786.-Jamaica, = Corticifera lutea of Hertwig, 1888.-Bermudas, probably not C. lutea, Quoy \& Gaim., 1833. - Tongatabou, [E. \& H.].

P. ocellata (Ellis \& Sol.), 1786.-Dominica, Jamaica, [M.].

P. glareola (Lesueur), 1817.-Guadeloupe, Bermudas, [M.].

P. flava (Lesueur), 1817.-St. Thomas, Bahamas, [M.].

P. tuberculosa, of Hertwig, 1888.-Cape of Good Hope; probably not P. tuberculosa, Klunz., 1877.-Red Sea, [E. \& H.].

P. howesii, Hadd. \& Shackl., 1891.—Torres Straits, [H. \& S.].

P. kochii, Hadd. \& Shackl., 1891.-Torres Straits, [H. \& S.].

P. ccesia?, Dana (fide H. \& S., 1891).-Torres Straits, [H. \& S.].

THE FOLLOWING PROBABLY BELONG TO THIS GENUS:-

P. aggregata (Lesson.), 1830.-Society Archipelago.

P. lutea (Quoy \& Gaim.), 1833.-CTongatabou.

P. flavo-viridis, Ehr., 1834.-Red Sea.

$P$. argus, Ehr., 1834.-Red Sea.

P. cosia, Dana, 1846.-Fiji.

P. glutinosa, Duch. \& Mich., 1866.-St. Thomas, probably $=P$. ocellata, (E. \& S.).

P. caribceorum, Duch. \& Mich., 1866.-St. Thomas.

P. cinerea, Duch. \& Mich., 1866.-St. Thomas.

P. tuberculosa, Klunz., 1877.-Red Sea. Probably neither of Hertwig nor of Studer, 1878.-New lreland.

P. culcuria, Müll., 1883. 


\section{SPHENOPUS, Steenstrup, 1856.}

Free solitary brachycnemic Zoantheæ, with a single, very long mesoglœal sphincter muscle. The body-wall is incrusted. Cell-islets are present in the mesoglœa.

\section{RECOGNIZED SPECIES.}

S. marsupialis, Steenstr., 1856.-Tranquebar, Pulo Faya, China Seas, Gray; (? Madras, H. \& S.), [H. \& S.].

S. marsupialis, var, bursiformis, Gray, 1867.-Massachusetts Bay, N. America. (This requires confirmation.)

S. arenaceus, Hertw., 1882.-Cape York, [H.].

S. pedunculatus, Hertw., 1888.-Philippine Islands, [E. \& H.].

\section{Sub-family. Macrocneming. \\ EPIZOANTHUS, Gray, 1867.}

Macrocnemic Zoantheæ, with a single mesoglœal sphincter muscle. The body•wall is incrusted. The ectoderm is usually continuous, but may be discontinuous; cell-islets in the mesoglœa. Diœecious polyps, connected by cœnenchyme, which may be band-like, incrusting, or greatly reduced, as in the free forms.

\section{RECOGNIZED SPECIES.}

E. incrustatus (Duib. \& Kor.), 1847.-Norway, [H. \& S.], = E. papillosus (Johnst.), 1842.-W. coast of Britain, [H. \& S.], = Sidisia barleei, Gray, 1858 (free variety).-Shetlands, [H. \& S.], $=E$. americanus, Verr., 1864 (and free variety).-E. coast of N. America, [H. \& S.], = E. cancrisocius of Hertw. (not of Studer), 1888.-Nova Scotia, [E. \& H.].

E. arenaceus (D. Ch.), 1836.-Mediterranean, 「H. \& S.].

E. couchii (Johnst.), 1838.-S. W. Britain, [H. \& S.].

E. norvegicus (Kor. \& Dan.), 1877.-Norway, [H. \& S.]. 
E. paguriphilus, Verr., 1882.-E. coast of N. America; W. coast of France; W. coast of Ireland, [H. \& S.].

E. parasiticus, of Hertw., 1882.-Japan (probably not of Verrill, 1862), [H.].

E. thatamophilus, Hertw., 1888. -Valparaiso, [E. \& H.].

E. stellaris, Hertw., 1888.-Philippines, [E. \& H.].

E. elongatus, Hertw., 1888.-Monte Video, [E. \& H.].

E. erdmanni (Dan.), 1890.-N. coast of Norway; Spitzbergen, [H. \& S.].

E. macintoshi, n. sp.-Shetlands, [H. \& S.].

E. wrightii, n. sp.-Dublin Bay, [H. \& S.].

PROBABLY BELONGING TO THIS SPECIES.

E. cancrisocius (Martens), 1875, ? of Studer, 1878.-Japan.

E. parasiticus, Verr., 1864.-E. coast of N. America.

E. abyssorum, Verr., 1885.-E. coast of N. America.

E. eupaguri(Mar.), 1882.

PARAZOANTHUS, n. g.

Macrocnemic Zoantheæ with a diffuse endodermal sphineter muscle. The body-wall is incrusted; the ectoderm is always continuous; the mesoglœa contains ectodermal canals, cell-islets, and an encircling sinus. Diøecious.

\section{RECOGNIZED SPECIES.}

P. axinellce (Schmidt), 1862.-Mediterranean, [E.], [H. \& S.].

$P$. anguicoma (Norm.), 1868. -Shetlands; W. Britain, [H. \& S. ].

P. dixoni, n. sp.-W. of Ireland, [H. \& S.].

P. dichroicus, H. \& S. 1891.-Torres Straits, [H. \& S.].

P. douglasi, H. \& S., 1891.-Torres Straits, [H. \& S.].

P. (sp.)? (Hertw.), 1888._-Tristan d'Acunha, [E.\& H.].

$P$. hertwigi, n. n.-Tristan d'Acunha, [E. \& H.], name proposed by us (see p. 616) for P. anguicoma, of Hertwig, 1888. 
SYSTEMATIC ACCOUNT OF THE BRITISH ZOANTHE

\section{ZOANTHIDA.}

\section{Brachychemine. (None British.) \\ II. Macrochemina.}

EPIZOANTHUS, Gray, 1867.

\author{
Spongia (pars), Johnston, 1834. \\ Dysidea? (pars), Johnston, 1842. \\ Mammiluifera (pars), Auct. \\ Zoanthus (pars), Auct.
}

Sidisia, Gray, 1858.

Carolia, Gray, 1867.

Polythos (pars), Andres, 1884.

Palython (pars), Carus, 1884.

Macrocnemic Zoantheæ, with a single mesogloal sphincter muscle. The bodywall is incrusted; the ectoderm is usually continuous, but may be discontinuous; cell-islets in the mesoglœea. Diœcious. Polyps connected by coenenchyme, which may be band-like, incrusting, or greatly reduced as in the free forms.

The genus Epizoanthus was established by Gray in 1867 for incrusted Zoantheæ: "II. coral attached; cells arising from a foliaceous expanded base. . . . The base expanded foliaceous (parasitic on shells); the cells cylindrical, simple, separate from each other from the base ; tentacles numerous " (p. 237). E. papillosus, Johnst., is his type. Verrill adopted Gray's genus. At first Hertwig (1882) agreed with Verrill in using this term to denote incrusted forms which rose above their cœnenchyme. After Erdmann's investigations, he (1888) restricted the genus to macrocnemic Zoantheæ, with "Integument incrusted, cœenenchyme (mostly?) lamellar; sphincter simple, mesoglœal; mesenteries arranged on the macrotype; colonies (mainly?) parasitic" (p. 37). We have studied the type species of this genus, and find that it does conform to Erdmann's and Hertwig's definition of the genus. We may add that all observers have agreed in relegating to this genus all those incrusted Zoantheæ which form carcinæcia.

In 1858. Gray erected the genus Sidisia for free Zoantheæ, "which may be characterized by the emission of buds on the surface of the cylindrical body" (p. 532), S. barleei being the sole species. He considered that this species "evidently belongs to quite a different group" from Dysidea papillosa, Johnst., which Mr. Barlee (in litt.) informed Gray "was a Zoanthus, allied to the genus Mammillifera of Lesueur," an opinion which Gray adopted.

Our investigations prove that $S$. barleei is only a variety of $E$. incrustatus ( $=E$. papillosus). We do not propose to keep the name Sidisia for the genus, although it has priority, and for this reason: it was solely erected for a species which is only 
a variety of an older form; and the name has only been occasionally retained for this variety of that particular species, whilst Epizoanthus has been universally adopted for the more typical forms of this genus. Both names were originated by Gray, and we have therefore less hesitation in keeping to the latter.

Erdmann examined some free Zoantheæ which were dredged by "H. M. S. "Triton,' 640 Fuss" (1885, p. 481). Without paying any attention to the literature of the subject, he relegated these to a new genus, which he did not name. Very likely it is the Shetland species. Danielssen (1890) described specimens which he referred to Erdmann's new genus, which he named Mardoll; and he called his new species $M$. erdmanni (p. 117). Through the courtesy of Dr. Danielssen we have been able to examine this form, and have cut sections of it. We are perfectly satisfied as to its specific distinction from the free variety of $E$. incrustatus.

The imperfect mesenteries of $E$. erdmanni are much more developed than in $E$. incrustatus; and there is almost invariably a well-marked lacuna in the mesogloea at the base of the insertion of each mesentery.

In every respect it is an Epizoanthus, the sphincter being mesoglœeal instead of endodermal, as Danielssen states, and the arrangement of the mesenteries is macrocnemic, though Danielssen's figures do not show this.

BRITISH SPECIES OF THE GENUS EPIZOANTHUS.
E. incrustatus, Diib. \& Kor., 1847.
E. paguriphilus, Verr., 1882.
E. couchii, Johnst., 1838.
E. macintoshi, n. sp.
(E. rubricornis, Holdsw., 1861.)
E. wrightii, n. sp.

\section{SYNOPSIS OF BRITISH SPECIES OF EPIZOANTHUS.}

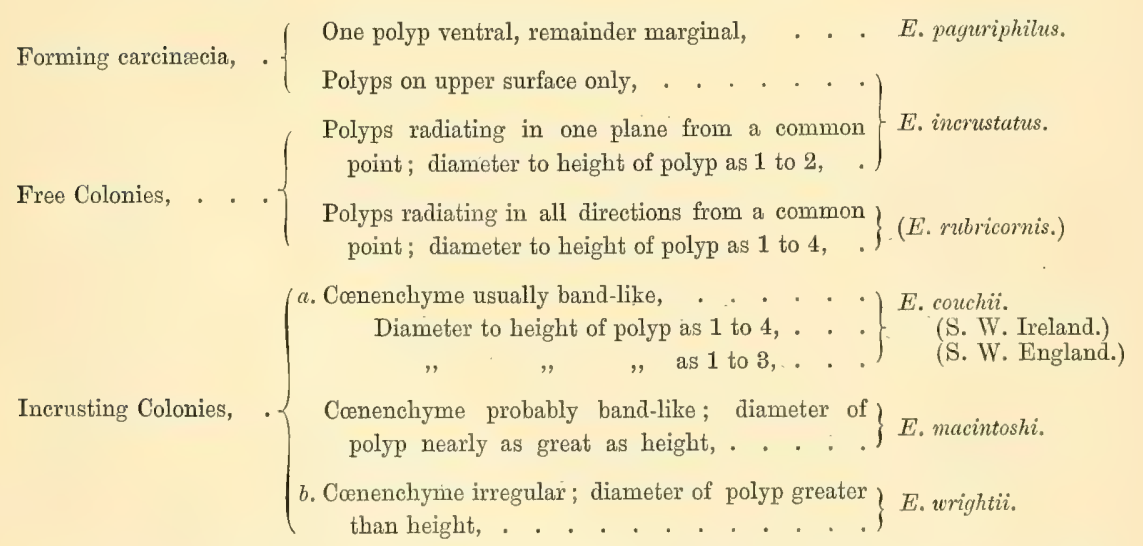

The above relative proportions of diameter to height refers solely to contracted spirit specimens. 
Epizoanthus incrustatus (Düb. and Kor.).

\author{
(Pl. LvirI., figs. 1-22 ; Pl. LIx., fig. 2 ; Pl. Lx., fig. 1.)
}

Spangia suberia :

Johnston, 1834, Loudon's Mag. Nat. Hist., vII, p. 431, fig. 60.

Dysidea (?) papillosa :

Johnston, 1842, Hist. Brit. Sponges, pp. 190, 251 (in part), fig. 18 (not pl. xvi., figs. 6, 7), Gray, 1858, Proe. Zool. Soc., p. 531.

Mammillifera incrustata :

Düben and Koren, 1847, Forhandl. Skand. Naturf. Möde, p. 268 ( $c f$. transl. in Isis, 1848, p. 536). Sars, 1851, Reise i Lofot. og Finm., Nyt Mag. Naturvid., v.. (2), p. 142. Danielssen, 1859, Nyt Mag. Naturvid., xI. (1861), p. 45.

Sidisia barleei :

Gray, 1858, Proc. Zool. Soc., xxrn., p. 532, pl. x., fig. 8. Gray, 1867, Proc. Zool. Soc., p. 237. Norman, 1868, Rep. Brit. Assoc. Adv. Sci., p. 319.

Zoanthus couchii :

(Not of Couch). Landsborough (in part), 1852, Brit. Zooph., p. 225. Holdsworth (in part), 1858, Proc. Zool. Soc., p. 557, pl. x., fig. 3 ; and 1859, Ann. Mag. Nat. Hist., (3), rv., p. 152. Var. diffusa, Gosse, 1860, Brit. Sea Anemones, p. 298, pl. זx., fig. 10; and var. liber, p. 298, pl. Ix., fig. 9. Var. M. incrustata, Alder, Trans. Tyneside Nat. Field Club, v.

Zoanthus incrustatus:

Sars, 1860, Forhandl. Vidensk., Christiania, p. 141 ; also Forhandl. Skand. Naturf. Möde. Kjöb., vII., p. 691. Norman, 1868, Rep. Brit. Assoc. Adv. Sci., p. 319.

Epizoanthus americanus:

Verrill, 1864, Mem. Boston Soc. Nat. Hist., I., pp. 34, 45 (addenda); 1866, Proc. Boston Soc. Nat. Hist., x., p. 335 (Gemmaria americana, Verrill, Am. Nat., II., p. 9, fig, 42) ; 1871, Am. Jour. Sci., I., p. 361. Dana, 1872, Corals and Coral Islands (2nd ed.), p. 62, figs. 1, 2. Verrill, 1873, U. S. Fish. Com. Rep., pp. 446, 510, pl. xxxvm., figs. 286, 287; 1874, Am. Jour. Sci., vir., p. 413 ; ibid. (3), хxшس., 1882, p. 316. Smith and Harger, 1874, Trans. Connect. Acad., III., pp. 9, 10, 11, 55, pl. vII., fig. 2. Verrill, 1883, Bull. Mus. Comp. Zool., хт., 1883-1885, p. 60, pl. vIn., figs. 1, 6 ; 1885, U. S. Fish. Com. Rөp. (1888), p. 534.

Epizoanthus papillosus:

Gray, 1867, Proc. Zool. Soc., 1867, p, 237. Ridley, 1886, Proc. Roy. Irish Acad. (2), iv., No. 5, Sci., p. 617.

Palythoa arenacea:

Carus, 1884 (not of D. Ch.), Prod. Faunæ Medit., p. 75.

Polythoa arenacea:

Andres, 1884 (not of D. Ch.), Le Attinie, p: 308. Pennington, 1885, Brit. Zooph., p. 182.

Epizoanthus cancrisocins :

Hertwig (not of Studer), 1888, Zool. Voy. "Challenger," Rep. Actiniaria, Suppl. LxxIII. p. 41, pl. 1., fig. 15.

Polythoa incrustata :

Bourne, 1890, Journ. Marine Biol. Assoc., I., p. 319. 
Form:-Thickly incrusted forms, of which the well-grown polyps are twice as high as broad. Two well-marked varieties:-A. Incrusting form, cœnenchyme forming carcinæcia by replacement of a gasteropod shell; the two primary polyps at each end of the shell, usually forming a well-marked posterior marginal row of polyps ; other polyps scattered on dorsal surface ; maximum number about 10-12, varying much in height; no polyps on the under surface of the carcinæcium. B. Free form, primarily consisting of two individuals base to base, each of which may divide more or less regularly, or one only may divide.

Colour.-Sandy.

Dimensions.-Polyps, 3-9 $\mathrm{mm}$. in height; $1.5-4.5 \mathrm{~mm}$. in average diameter. Colonies, greatest length, 22-35.mm. ; greatest breadth, 13-20 mm.

Locality.-Shetlands; W. and S. W. Ireland; N. E. England; Lerwick (Barlee); 30 miles E. and N. of Brassey I., 70-80 faths. (Barlee); Haaf, Shetland, 1863 (A. M. N.) ; 5-8 miles E. of Balta, Shetland, 40-50 faths., July 20-23, 1867 (A. M. N.), "commensal with Pagurus locvis" (Pl. LviI., figs. 1-13); also in St. Magnus Bay (A. M. N.); 40 miles S. W. of Cape Clear, Co. Cork, 80-90 faths., 1885, commensal with Eupagurus excavatus and Spiropagurus loevis (A. C. H.); Nymph Bank, Co. Cork, 50 faths., 1886 (A. C. H.); Clew Bay, 1890 ; 33-40 faths. off Aran, Co. Galway, 1891 (A. C. H.), (Pl. LvII., figs. 14-22); 33-36, Donegal Bay, 1891 (A. C. H.); Scarborough (Bean, f. Johnston); Northumberland, "deep water" (Alder); $48^{\circ} 59^{\prime} 42^{\prime \prime} \mathrm{N}$., $10^{\circ} \boldsymbol{7}^{\prime} 27^{\prime \prime}$ W., 90 faths., 1889 (G. C. Bourne), associated with E. meticulosus ; Plymouth Sound (specimens in Mus. of Marine Biol. Assoc. Laboratory).

The geographical distribution of this species is North Atlantic, extending from the east coast of N. America to N. W. Europe.

The synonymy of this species is much involved, but we think the foregoing list is sufficiently complete. We agree with Norman in rejecting Johnston's specific name, as he considered it to be a sponge; and some years later (Hist. Brit. Zooph., 2nd ed., 1847, p. 202) he quotes Couch's description of Z. couchii, and has "the pleasure of naming this the only European Zoanthus after its discoverer." It is therefore clear that he did not regard his own form as a Zoanthean. We are thus obliged to adopt the specific name given to this species by Diiben and Koren. Holdsworth, Gosse, and others have regarded this as a variety of E. couchii: we think that it will be admitted from our anatomical studies that this is not the case ; neither can it be associated with $E$. arenacens, D. Ch.

Owing to the kindness of Canon Norman we have been enabled to study some authentic Norwegian specimens of this species, and find them to be identical with the Shetland and Irish forms.

Dr. Gray had no hesitation in referring some specimens from the coast of Massachusetts, collected in forty-fathom water (Proc. Zool. Soc., 1867, p. 237), to 
this species. Verrill, however, erected a new species for the forms dredged off the east coast of N. America. Thanks again to Canon Norman's courtesy we have examined some of Professor Verrill's specimens, and we must confess to not being able to distinguish them specifically from the European examples. It is difficult to understand why Professor Hertwig ignored these two specific names and adopted for his specimen (Challenger Sta., 49, off Nova Scotia, 85 faths.) the name of a form from the Pacific Ocean. Verrill (1885) says it (incrusting variety) ranges from " $49-906$ fathoms; abundant."

The synonymy has also been complicated on account of the occasional free habit. This variety was first named Sidisia barleei by Gray. Gosse, Holdsworth, and others have regarded it simply as a variety of the typically incrusting Z. couchii. Verrill, too, recognises a free and an incrusting variety of E. americanus, and also for his E. abyssorum; of this latter he says: "This species generally forms the carcinæcia of Parapagurus pilosimanus, but sometimes consists of two or three large obconic polyps arising from a grain of sand" (l. c. 1885, p. 535).

Norman, however, in referring to this variety, says (1868, p. 319): "Taken abundantly in company with Zoanthus incrustatus, of which I was at one time inclined to consider it a variety; but more careful examination and dissection has convinced me that there are certain distinctions between the two, besides the fact of Sidisia being a free-living, unattached form. Whether these distinctions are specific or sexual, a careful examination of the living animal must hereafter determine." We have compared microscopically the two varieties, and find them to be essentially similar.

Incrusting Form.-Cœnenchyme incrusting gasteropod shells inhabited by hermit-crabs, the shells being rapidly absorbed and replaced by the cœnenchyme which thus forms the carcinæcium. In old specimens the polyps appear to be irregularly arranged; but on an examination of younger specimens, three series of polyps can be distinguished. In the youngest example we have seen (Pl. LVIII., fig. 14) there is only a single polyp, which is situated at the apex of a small gasteropod shell, the shell itself being entirely coated by the cœenenchyme. The second polyp arises at the oral axis, or hilum, of the shell (fig. 15). A third one usually makes its appearance above the mouth of the shell. We have seen several cases in which the apical polyp is in the act of fission (Pl. LVIII., fig. 12). These three polyps form the first series. The second series forms a marginal row which corresponds to the aboral varex of such a shell as Ranella. The third series forms an irregular row between the two former. In no specimen of the very large number we have examined is there a polyp on the under surface of the carcinæcium. The polyps bend slightly towards the oral or anterior aspect of the carcinæcium. In a contracted state the capitulum forms a 
flattened disc-like termination to the polyp, on which indistinct radii, usually about 18 or 20 in number, can usually be discerned. The disc-like termination is sensibly of greater diameter than the column of the polyp.

Free Form.-The earliest stage we have seen consists of two polyps base to base. These may divide by fission more or less symmetrically (Pl. LviI., figs. 5-11), or one polyp may divide repeatedly, and the other not at all (Pl. Lvm., fig. 2-4). The variations are so great that it would be impossible to attempt to describe them all; and we would here point out that the two species of Epizoanthus we have examined which have free forms (viz. E. incrustatus, E. erdmanni) vary in such a similar manner that the variations appear to have no taxonomic value; the same also holds good for $E$. abyssorum, Verr. We have seen specimens of similar varieties of other species which have not as yet been identified; one which comes from Naples will, we believe, be found to be a free variety of $E$. arenaceus. The size of the polyps and the character of the incrustations seem to be the only external features which distinguish the free forms of these species from each other, and these are obviously insufficient.

It is worthy of notice that the capitulum of the free varieties is usually less flattened than that of the incrusting forms.

The size which the polyps may attain apparently varies with the locality; for example, the largest of the Shetland specimens are $9 \mathrm{~mm}$. in height, by $4.5 \mathrm{~mm}$. in diameter; the largest colony from Balta measuring $30 \times 20 \mathrm{~mm}$; that from Haaf being $35 \times 20 \mathrm{~mm}$. In the free variety the fully grown polyps average 6-7 mm. high, and $3-3.5 \mathrm{~mm}$. across; the larger colonies being $22-23 \mathrm{~mm}$. long by $8-11 \mathrm{~mm}$. broad. From the S. W. of Ireland, the polyps range up to $7.5 \mathrm{~mm}$. high by 3.5 in diameter, the carcinæcia being $24 \times 15 \mathrm{~mm}$. The W. of Ireland specimens from off Aran and from Donegal Bay run a good deal smaller: the polyps average $3-6 \mathrm{~mm}$. in height and $1.5-3 \mathrm{~mm}$. in diameter; most of the colonies are quite small, the largest being $22 \times 13 \mathrm{~mm}$. The nature of the incrustations also gives them a black-gray colour. The difference in size and colour between these and more normal specimens is so marked as to constitute a distinct variety.

Verrill's original description (1866, p. 34) of this species (his Epizoanthus americanus, n. sp.) is as follows:-"This species, which is parasitic on shells, has an incrusting base, smooth and uniform on the lower side of the shell, but giving rise to from fifteen to twenty polyps on the upper side, which diverge in all directions. Polyps variable in height and size, those of the upper central portion generally half an inch in height $(13 \mathrm{~mm}$.) and one-eighth $(3.25 \mathrm{~mm}$.) in diameter; while those around the margin of the base are not more than half so large, and much crowded. Base spreading over and completely investing dead shells of Natica, Buccinum, \&c., both externally and internally. The substance of the 
shell in every case has been entirely removed, but the form in all parts is perfectly preserved by the membranes of the polyps, while the cavity is inhabited by a species of hermit crab (Eupagurus pubescens). Column pillar-like, smallest in the middle, increasing gradually below, but enlarging rapidly at the summit. Walls thin, covered by a layer of closely adhering fine sand. When contracted, the summit is slightly concave; and in the medium-sized polyps has seventeen, in the largest twenty-four sulcations, radiating from the centre, which is seldom completely closed. Tentacles, forty-eight or more, short, conical.

The localities at which this species had been obtained up to that time are given by Verrill in 1882, p. 316 . The free or type-form (of $E$. americanus, Verr.) occurred at 28 stations, 28 to 487 fathoms, whereas the incrusting variety "(= Zoanthus norvegicus, Kor. \& Dan.)" occurred at 11 stations, 69-160 fathoms. The former is by far the most abundant numerically. Later (1885), he gives the bathymetrical range of the free form as " $26-547$ fathoms; generally diffused and very abundant" (p. 534); and of the incrusting variety, "49-906 fathoms; abundant" (p. 535).

Smith and Harger (1874) report this species from off the coasts of New Jersey to the Gulf of St. Lawrence; the specimens with incrusted shells inhabited by Eupagurus pubescens came from 60-65 fathoms; while those from 430 fathoms were on stones and on hydroid stems. The figure, which is of a magnified polyp, is of no real value.

In Verrill's last Paper (1885, p. 60), he says it is mostly commensal with Eupagurus politus, Smith, and E. kröyeri, very common; those on grains of sand (free variety) were even more abundant. Some occurred incrusting sponges, shells, hydroids, tunicates, gorgonia, Paramuricea grandis, pebbles, \&c. The original specimens off New Jersey, 30 fathoms, were commensal with E. pubescens. We think it possible that more than one species has been identified by our American colleague as E. americanus.

Body-wall (Pl. LIX., fig. 2). - The incrustations in this species are numerous, and consist for the most part of coarse grains of sand, so that it is difficult to make out the structure of the body-wall from our sections. The ectoderm is continuous, and is covered by a cuticle, to which diatoms and dark granules are attached. Nematocysts, containing similar granules, are usually abundant in the ectoderm. The incrustations are embedded in the mesogloea throughout its entire thickness, often protruding into the coelenteron. Single cells are occasionally found enclosed in the mesoglœa; and lacunæ are sometimes found near the union of the mesenteries with the body-wall; but the mesogloea is for the most part devoid of cell enclosures. The usual endodermal muscular layer is present, being especially well-developed in the upper part of the column. The endoderm is formed by a thin layer of columnar cells of uniform height. 
Sphincter muscle.-The mesoglœal sphincter muscle is short, and consists of well-defined cavities.

Disc and Tentacles.-The disc and tentacles present the usual structure. The muscular layers appear to be feebly developed.

Esophagus.-The shape of the cesophagus in cross-section varies in our specimens. Sometimes it is almost circular (Pl. Lx., fig. 1), the groove forming a very slight depression; in other specimens the groove is fairly-well marked. The ectoderm is almost smooth, being but very slightly folded.

Mesenteries. - The arrangement of the mesenteries is macrocnemic. The imperfect mesenteries are very slightly developed, extending into the coelenteron but little beyond the endoderm. The ectoderm of the oesophagus is reflected, and forming a series of folds along each mesentery, is continued downwards in the usual manner to form the mesenterial filaments. The mesogloea of the mesenteries is slightly developed. The muscle-fibres form simple layers, there being no mesoglœal plaitings. The endoderm of the mesenteries is thin, resembling that of the body-wall.

Gonads.-There were no gonads in the specimens examined by us.

Var. barleei.-The specimens we have cut of the free variety agree very closely in their anatomy with the above account; but the sphincter muscle appears to be longer and more powerful.

\section{Epizoanthus paguriphilus.}

(Pl. LviII., figs. 23-25 ; Pl. LIx., fig. 6 ; Pl. Lx., fig. 5.)

\section{Epizoanthus paguriphilus:}

Verrill, 1882, Am. Journ. Sci. (3), xxur., pp. 137, 316 ; 1883, Bull. Mus. Comp. Zool., Cambridge, Mass., xI. (1883-85), p. 61, pl. vп., fig. 5 ; 1884, Am. Fish. Com. Rep. for 1882, p. $658 ; 1885$, Am. Fish. Com. Rep. for 1883, p. 535, pl. vni., fig. 28. Bourne, 1890, Journ. Marine Biol. Assoc., I., p. 318.

Zoanthus (Corticanthus) paguriphilus:

Andres, 1884, Le Attinie, p. 326.

Form.-Colonies always forming carcinæcia; slightly incrusted; mesoglœa very thick; one polyp on ventral surface, the remainder forming a radiating single row, the "posterior polyp" of which is the smallest.

Colour.-Brownish in spirit specimens, but bluish-gray in colour where the thin incrustation is rubbed away.

Dimensions.-Average diameter of cœnenchyme, $55 \mathrm{~mm}$.; average height of polyps, $20-25 \mathrm{~mm}$.; average width of polyps, $12-16 \mathrm{~mm}$. ; average thickness of polyps, 8-10 mm. 
Locality.-W. and S. W. Ireland:- $50^{\circ} 29^{\prime} 26^{\prime \prime}$ N., $11^{\circ} 4^{\prime}$ W., 400 faths., July 11, 1889 (G. C. Bourne) : 500 faths., 54 miles off Achill Head, Co. Mayo, July 10, 1890 (A. C. H.), (PI. LviII., fig. 25). The specimens figured on Pl. LVIII., figs. 23, 24, are in the British Museum; they came from 71 miles W. by S. of the Fastnet, 315 faths., and possibly also from deeper water ( $f f$. Ann. Mag. Nat. Hist. (6), Iv., 1889, pp. 411, 430).

The geographical distribution of this species is North Atlantic, extending from the N. E. coast of America to N. W. Europe, in deep water.

This is the largest and most striking of the species of British Zoanthex, and is quite a recent addition to our fauna.

The polyps are in two positions, one central and inferior, the remainder marginal, divergent, and uniserial. The cœnenchyme entirely surrounds the shell on which it grows, save for the orifice through which the commensal hermitcrab emerges. The orifice is ventrally situated, and is about $5 \mathrm{~mm}$. distant from the anterior border of the carcinæcium, and is from about $15-20 \mathrm{~mm}$. in diameter.

Immediately behind the orifice is a polyp, which in spirit-specimens does not rise above the general surface of the cœenenchyme, and is less than $10 \mathrm{~mm}$. in diameter.

The marginal polyps are prominent, and elliptical in section. At the posterior end of the carcinæcium one polyp ean readily be distinguished as being markedly smaller ( $15 \mathrm{~mm}$. in height) than the other marginal polyps; this we term the "posterior polyp." There are in the three specimens which we have examined four well-grown polyps to the left of the posterior polyp, and four, five, and six, respectively, on the right side of the carcinæcium.

There is a space of $20 \mathrm{~mm}$. between the right and left polyps on the anterior convex border of the carcinæcium. Under-surface of the carcinæcium flat; upper surface irregularly convex, with the greatest prominence towards the right.

A young specimen, which one of us dredged off the $\mathrm{W}$. of Ireland, and which is drawn of the natural size in Pl. LvII., fig. 25, shows that the order of the appearance of the polyps is probably as follows:-(1) the ventral polyp; (2) the posterior polyp; (3) the right and left anterior polyps ; (4) the succeeding lateral polyps, of which the most posterior are the youngest. After four pairs of marginal polyps have appeared the further production of polyps appears to be confined to the right side.

This species is always commensal with Eupagurus pilosimanus.

Verrill first described this species in 1882 in the following terms:- "Polyps few and very large, stout, with broad, swollen bases, arising from a very thick, smooth, lubricous, gray or mud-coloured, translucent cœnenchyme, which at first invests small univalve shells, occupied by Parapagurus pilosimanus, but finally grows far larger than the shell, and eventually absorbs it. Dise broad, larger 
than column; tentacles numerous, rather long, light orange. Breadth of colony, 2 to 3 inches; height of polyps in expansion, 1 inch or more; diameter, .5 to $\cdot 7$ of an inch" (p. 137). He further adds:- " Hitherto it has not been found elsewhere than upon the back of this particular species of crab, which, likewise, has not been found without its polyp. Of these associated creatures we took about 400 couples, at station 947 , in 312 fathoms, at one haul. It had previously only been known by a few specimens taken by the Gloucester halibut fishermen, in deep water, off Nova Scotia, and by ourselves in 1880." On p. 316 of same journal (Am. Jour. Sci. (3), xxiII.) he adds :- " [Station 947, S. by W. $\frac{3}{4}$ W, 89 miles off Martha's Vineyard, sand, mud, Aug. 9, 1881 ; temperature $44^{\circ} \mathrm{Fr}$. U. S. Fish. Com. Rep. for 1882-1884, p. 643]." "Epizoanthus paguriphila, Verrill, sp. nov., 252-458 faths." -and gives a list of the stations at which it was obtained.

In the Bulletin Mus. Comp. Zool. Cambridge, Mass., Verrill gives the colour as translucent bluish or purplish-gray, or grayish-brown. In fresh specimens the tentacles are pale-orange or salmon, with lighter tips, and polyps more or less of a salmon-colour. The diameter of ordinary specimens, 60-70 mm.; vertical thickness, 25-30 mm.; length of polyps, $15-20 \mathrm{~mm}$.; diameter in middle, 10-12 mm.; and at base, $12-18 \mathrm{~mm}$. Some specimens considerably larger than this were obtained. There are seven to twelve polyps.

Body-wall (Pl. LIx, fig. 6).-The ectoderm is not continuous, but is penetrated by strands of mesogloea, which unite (as in $Z$. coppingeri and other species of Zoanthus and of Isaurus, and also in G. macmurrichi, to form a peripheral layer of mesoglœa. This peripheral layer of mesogloea is not distinguishable from the cuticle which covers the body. A more deeply stained outer layer may often be seen, but it appears to be simply due to the shrinking of the edge of mesogloea under the action of heat. The columnar cells of the ectoderm are closely packed, and stain deeply. They often contain dark pigment granules. Nematocysts filled with similar pigment-granules are frequently found amongst them. The few foreign particles (chiefly foraminifera and grains of sand) which incrust this species are generally found partly embedded in the ectoderm and partly in the adjacent mesoglœa. The mesoglœa is remarkably thick, being relatively much thicker than in any other species of Zoanthean examined by us. In section the mesogloea appears to enclose numerous "cellislets." Some of these, however, are much elongated, and might possibly be regarded as forming parts of canals. We have not been able, however, to trace any distinct canals arising from either ectoderm or endoderm; and it seems more probable that all these cell enclosures are completely surrounded by mesogloea. The usual spindle-shaped cells drawn out into long fibres can be discerned running through the mesoglœa. The endodermal muscular layer is not very well 
dereloped; the fibres are supported on slight, rounded plaitings of mesogloea. The endoderm consists of a single layer of columnar cells, the peripheral portion of the cells being of a deep brown colour owing to the presence of pigmentgranules.

Sphincter muscle.-The single mesogloeal sphincter is not a very powerful one. No cavities are visible, the fibres being completely embedded in the substance of the mesoglœea.

Tentacles.-The ectoderm of the tentacles is thrown into transverse folds. Numerous pigment-granules are to be found amongst the usual small nematocysts, and the nuclei in the peripheral portion. The muscular layer is not well developed. The mesoglœa forms an extremely thin layer. The endoderm is also pigmented.

Disc.-The disc is very similar in structure to the tentacles.

Esophagus.-The eetoderm of the osophagus is thrown into numerous folds. There is a well-marked groove. The mesogloea forms a thin layer, except in the region of the groove where it is somewhat thicker. It contains a few cell-islets.

Mesenteries.-The mesenteries have the usual macrocnemic arrangement. The reflected ectoderm of the œsophagus is attached to them in the lower part of the œsophageal region and lower down forms the filaments as in other Zoantheæ. The mesoglœa is well developed in the œsophageal region, and here, on one side of each mesentery, plaitings which support the longitudinal fibres can be distinctly seen. Plaitings on both sides of the mesentery nearer to the bodywall which support the parieto-basilar fibres are exceedingly slight. The mesogloa is much thinner in the lower part of the body. The endoderm is very similar to that which lines the body-wall.

Gonads.-The sexes are distinct. Male gonads are present in our sections; they are very numerous, and closely packed together, almost entirely filling up the body-cavity below the œsophagus (Pl. Lx., fig. 5).

\section{Epizoanthus couchii (Johnston).}

(Pl. LviII., figs. 26-28 ; Pl. LIX., fig. 4 ; Pl. LX., fig. 3.)

\section{Zoanthus couchii:}

Johnston, 1838, in Couch, Cornish Fauna, III., p. 73, pl. xv., fig. 3 (not of Thompson, 1843, Br. Assoc. Rep., p. 284; nor of Thompson, 1844, Ann. Mag. Nat. Hist., xir., p. 440; nor of Landsborough, 1845, ibid., xv., p. 327 ; all of which are Sarcodictyon catena, ef. Johnston, 1847, l.c., p. 180). Forbes, 1844, Ann. Mag. Nat. Hist., xrv., p. 415. Johnston, 1847, Brit. Zooph., ed. 2, p. 202, pl. xxv., fig. 9. Landsborough, 1852 (in part), Brit. Zooph., p. 225. Thompson, 1856, Nat. Hist. Ireland, Iv., p. 462; Holdsworth, 1858 (in part), Proc. Zool. Soc., p. 557, pl. x., figs. 4-7. Wright and Greene, 1858, Brit. Assoc. Rep., p. 180. Gosse, 1860, var. linearis, Brit. Sea Anem., p. 297, pl. x., fig. 5. Hincks, 1861, Ann. Mag. Nat. Hist. (3), vाI., p. 363. 
(Dysidea (?) papillosa :

Johnston, 1844, Hist. Brit. Sponges (in part), pp. 190, 251, pl. xvı., figs. 6, 7.

Carolia couchii :

Gray, 1867, Proc. Zool. Soc., p. 239.

Palythoa couchii:

Fischer, 1874, Nouv. Arch. Mus., Paris, pp. 235, 239 ; 1874, Comptes rendus, Lxxrx., p. 1209 (trans. 1875, Ann. Mag. Nat. Hist. (4), xv., p. 374); 1875, Actes Soc. linn. Bordeaux, xxx., p. 8.

Polythoa arenacea :

(Not of D. Ch.) Andres, 1884, var. couchii, Le Attinie, p. 308; Pennington, 1885, var. linearis, Brit. Zooph. (in part), p. 182.

Palythoa arenacea:

(Not of D. Ch.) Carus, 1884, Prod. Faunæ Medit., p. 75.

Form.-Column cylindrical, rising to about three or four times its diameter. Margin cut into 12 or 14 (generally the latter number) large, fleshy, triangular teetli, which are connected by a thin web of transparent membrane. In a state of semicontraction these teeth form strongly marked, converging ridges on the flat summit of the column. Incrustations of fine sand. When the column is much distended, the grains of sand become considerably separated, and the visceral cavity can be seen through the transparent and smooth integuments. Dise, generally flat or slightly concave, but protusile in a conical form; radii distinct. Tentacles 28 (or 24), bicyclic, those of the inner row correspond to the marginal teeth; they are subequal, they taper gradually, are bluntly pointed, and about equal in length to the diameter of the column. Coenenchyme, narrow, irregularly creeping, soft, invested with sand like the column.

Colour.-Column and coenenchyme pale brown; dise pellucid, reddish-gray, dusted with excessively minute white specks; tentacles translucent, nearly colourless, opaque white tip; lip opaque white.

Dimensions._" One-eighth of an inch [3 $\mathrm{mm}$.] in diameter, and about thrice that height $[9 \mathrm{~mm}$.] in extension. In contraction the button is usually about a line [2 mm.] in height. Mr. Holdsworth has obtained specimens much larger than these."

Habitat._" var. linearis.-The condition above described, in which the rootband creeps in a narrow ribbon over stones and shells. Cornwall and Devon."

The foregoing description is taken from Gosse, and refers to the specimens he had seen alive; perhaps he has incorporated older observations in it.

We have not been able to see any specimens of this species from the recorded localities, although we have made numerous efforts to do so. Our generous friend Canon Norman put some Zoantheæ from the Channel Islands at our disposal, which bear a very strong superficial resemblance to $E$. couchii, as defined 
above; unfortunately they had been dried at some time or other, although they were in spirit when we had them, and though we made sections of them we could not make any satisfactory observations.

In order to facilitate the work of future observers we abstract all the additional information about this species, which is valuable from a descriptive point of view.

Johnston (1847) defines the genus and species as follows:- "Zoanthus: polypes distant, united by a creeping, root-like, fleshy band. Z . couchii: body cylindrical; tentacula in several circles." In quoting from Couch he adds the following details :- "It is a very small species ... of a light sandy or opaque red colour, and its surface is minutely glandular [this is an error of observation, and probably refers to the grains of quartz]. In its contracted state it is subconoidal, resembling both in shape and size a split pea. When semi-expanded it elevates itself to about twice its former height, and becomes contracted about its middle into an hour-glass form. When fully expanded the tentacula become distended and elongated to about the length of the transverse diameter of the body ; and they are generally darker at their extremities than towards the base."

Holdsworth (1858) obtained some specimens from 10-12 fathoms off Torbay. "One group of six polypes on the inside of a valve of Cardium rusticum is arranged in a linear series ; ... others are scattered over the surface of a flat stone, and have no perceptible connexion with one another, except in a few instances when two or three of them are united. ... The body forms a cylinder from 2 to 4 lines [about $4 \cdot 5-9 \mathrm{~mm}$.], by about half that in breadth, and is clothed with a dense coating of fine sand, which at the upper extremity is divided into 14 deeplycut, marginal teeth; these cover the top of the column when the animal is closed. The tentacula are moderate in length, slightly tapering, smooth. ... They are arranged in two rows containing 14 each, of which the inner series are rather the longer, and are placed opposite the angular prolongations of the column, those of the outer row alternating with them.... The general colour of the disc and tentacula is a pale transparent brown, becoming opaque white around the mouth and at the tips of the arms, and all the intermediate parts are finely speckled with the same tint." The following year (1859) he obtained some much larger specimens from Torbay.

Hincks (1861) says, "Not uncommon: Salcombe Bay [Devonshire], on slate, stone, \&c. (in about 12-15 fathoms)."

The following is a description of an Epizoanthus dredged by one of us in the S. W. of Ireland, and which we refer with some hesitation to this species. If E. rubricomis should prove to be a different species from $E$. couchii, our form will probably be found to be the same as the former, although the tentacles are of a different colour, and the habit of growth is different. 
Form.-The column is elongated, tapering from above downwards; the bodywall is well incrusted, but when the sand is rubbed off, the body-wall is thin and translucent. The capitulum has about 14 ridges; these may be present or absent in preserved specimens; in the latter case their absence appears to be due to their being rubbed when in the dredge. Tentacles bicyclic, about 14 in number in each cyle, the inner being slightly the longer and more curved. Mouth linear, on a slight cone. Coenenchyme, thin, either band-like, or forming small expansions.

Colour.-Sandy, sometimes dull, tawny-orange when alive; dise translucent buff, lips white, pale radii ; tentacles translucent buff, opaque-white spot at tip.

Dimensions.-Usually about 10-14 $\mathrm{mm}$. in height, and 2-3 mm. in diameter at the top of the contracted specimens, occasionally reaching a height of $18-20 \mathrm{~mm}$., with a diameter of $4 \cdot 5-5 \mathrm{~mm}$.

Habitat.-S. W. Ireland; about 30 miles off Cape Clear (Pl. LviII., figs. 27, 28), 80 fathoms; 40 fathoms off Glandore, Co. Cork ; Berehaven, Bantry Bay, 10 fathoms (A. C. H.), (Pl. LvIII., fig. 26), [Proc. Roy. Irish Acad. (2), IV., Sci., 1886, in which Report Mr. S. O. Ridley identified this form as Palythoa arenacea (?), D. Ch., p. 617].

The Rev. Canon Norman has sent us specimens of an Epizoanthus from Birterbuy Bay, Co. Galway. They were unfortunately too badly preserved for us to be able to study them minutely, but at all events the sphincter muscle closely resembles that of our specimens from S.W. of Ireland, and externally they agreed fairly well with the English specimens of this species. Some very similar Channel Island specimens (identified as "Z." couchii), which he gave us at the same time, probably belong to this species.

Fischer's (1874) description is as follows:- "The base of the colony is clothed with a layer of agglutinated sand, extending more or less; the polyps, irregularly disposed, have their column protected by a coating of sand; this is cylindrical and elongated when completely extended ; colour cindery-gray; the superior border has 14 to 15 teeth. The tentacles, disposed in two rows, are short, whitish, and to the number of 28-30. The dise is whitish; the mouth small, transverse."

The specimens came from "Arcachon, from 20-45 brasses. The colonies were fixed on to the shell of Chenopus pes-pelicani, which gives lodging to a Sipunculus. Alder has identified it at Guernsey. MI. Sauvage has obtained it at Boulogne on Pecten maximus, dredged in the channel" (p. 235). In his "bathymetrical distribution" he records this species on the oceanic coasts of France, from the Nullipore zone (28-72 metres), p. 239. The other Papers are merely abstracts.

To sum up the history of this species we may put the present state of our knowledge in this form. Johnston quotes Couch's description of the Cornish type specimens. Gosse, Holdsworth, and Hincks obtained Devonshire specimens which are probably the same as the former. Forbes identifies it as having been dredged 
by Mac Andrew in Loch Fine, W. Scotland, in 1844. Thompson records it as having been dredged by himself and Hyndman in 1835 and 18t6, 15-20 fathoms, from Strangford Lough (N.E. Ireland). Wright and Greene copy this. It may or may not be this species. We now describe specimens from S. W. Ireland which may possibly be this species: Fischer identifies it from the N. and W. coasts of France. Andres and Pennington merely quote Gosse.

Body-wall (Pl. LIx., fig. 4). - The body-wall is extremely thin in this species. The ectoderm, where present, is continuous, and is covered by a thin cuticle. It contains occasional nematocysts. Incrustations, which consist ehiefly of grains of sand, are fairly numerous. Cell-enclosures are very rare. The endoderm is very thin, and of uniform thickness. The muscular layer is rather feebly developed.

Sphincter muscle. - The single mesogloal sphineter is well developed, although it is not so powerful as in the free variety of $E$. incrustatus. It consists of elongated cavities which are well filled with muscle-fibres, the cavities forming for the most part a single row (Pl. LX., fig. 3).

Disc and Tentacles.-The structure of the dise and tentacles is for the most part as in other species of Zoantheæ; but oval nematocysts, similar to those which are found in the ectoderm of the body-wall and of the œsophagus, are present in the ectoderm of the tentacles of more than one of the specimens which we have cut. We have not, however, found them in all our specimens.

Esophugus.-The ectoderm of the osophagus is thrown into folds which appear to be deeper as a rule in the short than in the longer specimens. There is a wellmarked groove. Nematocysts are generally to be found in this region; but in one or two specimens we have not been able to find them. In some cases they are very abundant. Sometimes they appear to eontain black pigment-granules. In other cases they are quite clear, containing a distinct, coiled thread.

Mesenteries.-The mesenteries present the usual macrocnemic arrangement. The imperfect mesenteries are fairly well-developed. The longitudinal muscles are borne upon mesoglœal plaitings which are frequently well-marked, but in some of our specimens they are much slighter than in others. Nematocysts are very abundant in the ectoderm, which forms the mesenterial filaments in the usual manner.

Gonads.-We found no gonads in any of our specimens. 
[Epizoanthus arenaceus (D. Ch.), (not British, Mediterranean). (Polythoa (str. s.) arenacea. Andres, 1884, p. 308. Type var. Palythoa arenacea, Carus, 1884. p. 75.)

$$
\text { (Pl. LIX., fig. } 7 \text {; Pl. LX., fig. 4.) }
$$

Form.-Column eylindrical. Body-wall; thick and opaque, sometimes transversely wrinkled, about 15 capitular ridges and 30 tentacles; cœnenchyme incrusting, with a tendency to form linear bands.

Colour.-Dirty sand (in spirit).

Dimensions.-Height, 7-12 mm.; diam., 3.5-4.5 mm.

The above description is taken from specimens identified at the Naples Zoological Station. It will be seen that $E$. arenaceus differs from $E$. conchii, chiefly in the great thickness of its body-wall, which gives it a very characteristic appearance (Pl. LIX., fig. 7). Our specimens were not well preserved, and we have therefore some difficulty in determining satisfactorily anatomical characters. The mesoglœal sphincter muscle differs from that of $E$. couchii in the appearance of its cavities, the muscle-fibres being arranged in a single row round the mesogloea, leaving an empty space in the centre of the cavity (Pl. Lx., fig. 4). The thickness of the body-wall can be well seen in transverse sections. Nematocysts are present in the ectoderm of the cosophagus, and in the mesenterial filaments.]

\section{Epizoa th macintoshi, n. sp.}

(Pl. LvIII., fig. 29 ; Pl. LIX., fig. 1.)

Form.-Short, very stout, rigid column, incrusted with foraminifera which give it a very characteristic, white, granular appearance. Upper surface of contracted column with 18 radial ridges. Cœnenchyme apparently linear, of same nature as the wall of the column.

Colour-Grayish white.

Dimensions.-(In spirit) one polyp, $7 \mathrm{~mm}$. high by $6 \mathrm{~mm}$. in diameter; the other, $5 \mathrm{~mm}$. high by $4.5 \mathrm{~mm}$. in diameter.

Locality.- Shetlands (1871).

A small colony of three specimens of this species was kindly handed over to us by Dr. W. C. M'Intosh, F.R.S., Professor of Zoology at St. Andrews. One of these we devoted to the microtome; the remaining specimens are in Prof. M'Intosh's collection. We are pleased to be able to associate such a well-marked species with the distinguished Scottish Zoologist who has placed his collection of Actinix at our disposal. 
Body-wall (Pl. LIx., fig. 1).--The ectoderm is much broken, owing to the incrustations. Where present it is continuous, and is covered by a thin cuticle. Thread cells, containing a few, almost black, pigment-granules, are occasionally to be met with amongst the columnar cells of the ectoderm. The mesogloea is thinner relatively to the diameter of the column than in most species of Zoanther. The incrustations consist almost exclusively of foraminifera, which are frequently so large that a single specimen extends right across the body-wall, and is partly embedded in the ectoderm and partly in the endoderm, as well as in the mesogloea. There are hardly any cell-enclosures in the mesogloea. Single cells only are occasionally to be seen enclosed. The endodermal muscular layer appears to be fairly well developed. The endoderm is formed by a thin layer of columnar cells of uniform height.

Sphincter muscle.-The single mesogloeal sphincter is thick, extending right across the wall of the capitulum. The cavities in the mesoglœa are large.

Dise and Tentacles.-The nuclei of the ectoderm are diffused, and do not form a central band. The muscular layers are well developed.

Esophagus.-The ectoderm of the œsophagus appears to be quite smooth, not being thrown into folds. The groove is well marked, and there is a slight thickening of the mesoglœa in this region.

Mesenteries.-The arrangement of the mesenteries is macrocnemic. Owing to the presence of a parasitic crustacean in the single specimen we have cut it is difficult to determine the details regarding the mesenteries. The imperfect mesenteries extend but a short way into the body-cavity. The mesogloea is well developed, and is thrown on one side of each mesentery into distinct plaitings, which support the longitudinal muscle-fibres. The parieto-basal muscles are less well developed, and appear to extend but a short way from the body-wall.

Gonads.-We found no gonads.

Parasitic Crustacean.- - It is impossible to determine the nature of the crustacean infesting our specimen, or to say whether it is a fully developed or a larval form.

[Epizoanthus norvegicus (Kor. \& Dan.). (Not British, Norway.)

(Pl. LIX., fig. 5.)

Form.-Rather more clavate than E. macintoshi; cœnenchyme forming expansions, in which the polyps, in the specimens we have examined, appear to have a tendency to form linear series.

Colour.-Sandy browia (in spirit).

Dimensions.--Height, 6-12 mm. ; diam., about $6 \mathrm{~mm}$. 
We are again indebted to our friend Canon Norman for specimens (identified by Danielssen) of this species. Outwardly it differs from $E$. macintoshi in the rather more clavate form mentioned above, and in the darker and more brownish colour. Our specimens of either species are not sufficiently numerous to lay much stress on the difference in the cœnenchyme, which in many species varies much according to the nature of the body to which the polyps are attached. Anatomically the two species can be readily distinguished. The ectoderm of the body-wall in $E$. norvegicus is very thick, and is crowded with nematocysts (Pl. LIx., fig. 5). In $E$. macintosh $i$ the ectoderm is very thin relatively to the diameter of the column, and contains very few nematocysts (Pl. LIX., fig. 1). The incrustations in $E$. norvegicus are various, consisting of spicules, grains of sand, and foraminifera. In E. macintoshi they consist almost exclusively of foraminifera. The endoderm also in $E$. norvegicus is much thicker than in $E$. macintoshi. The imperfect mesenteries in $E$. norvegicus are remarkably well developed. In E. macintoshi they are feebly developed, extending a very short way into the body-cavity.]

\section{Epizoanthus wrightii, n. sp.}

(Pl. LvIII., figs. 30-33; Pl. LIx., fig. 3 ; Pl. LX., fig. 2.)

Form.-Column somewhat thick-set, body-wall incrusted but not particularly rigid, 16 capitular ridges, mouth a narrow slit, with one œesophageal groove; tentacles 32 in number, bicyclic, transversely corrugated when not fully extended. Cœnenchyme broad, flat, irregular. Polyps arise from the cœnenchyme; craspeda ejected from the mouth when irritated.

Colour.-Dirty pellucid-white or orange-pink; in both the disc is speckled with opaque white; tentacles with an opaque white tip; craspeda, white or orange-pink, according to the colour of the polyp.

Dimensions. - Height, $13 \mathrm{~mm}$.; diameter of column, $8.5 \mathrm{~mm}$.; diameter of disc, $13 \mathrm{~mm}$.; length of tentacles, $13 \mathrm{~mm}$. Average height of expanded spirit specimens, $4 \mathrm{~mm}$. ; average diameter of column, $3 \mathrm{~mm}$. In the contracted specimens the height and diameter are about equal, or the latter may even be the greater.

Habitat.-Dalkey Sound, Dublin Bay; between tides; spreading over incrustations on the granite rocks but never actually attached to the granite itself.

We are indebted to the brothers Dixon, for these specimens, and the above description is mainly taken from an account recently published by them ("Notes on the Marine Invertebrate Fauna of Dublin," Proc. Roy. Irish Acad., ser. III., vol. ii., p. 29, 1891). They very kindly placed all their specimens at our disposal. We have the pleasure of dedicating this species to our friend Dr. E. Perceval 
Wright, who is so well-known as a student of the Actinozoa, and who is always so ready to help his scientific colleagues.

Body-wall (Pl. LIx., fig. 3).-The ectoderm, where present, is continuous. It consists of numerous granular and deeply staining columnar cells, with occasional nematocysts seattered amongst them. It is protected by a thick cuticle, which does not stain but is of a dark brown colour owing to the presence of dark brown granules and of various foreign bodies. Incrustations chiefly consisting of coarse grains of sand, with a few foraminifera, are embedded in the mesoglœa, which contains very few cell-islets or other enclosures. The endoderm is formed by a rather thin layer of ordinary columnar cells. The endodermal muscular layer appears to be but slightly developed.

Sphincter muscle.-The single mesogloeal sphincter consists of several rows of simple cavities at the distal end. Proximally it is reduced to a single row of very small cavities (Pl. Lx., fig. 2).

Disc and Tentacles. - There is little worthy of note in the structure of the dise or tentacles. Both ectodermal and endodermal muscular layers are well developed.

Esophagus.-The ectoderm of the œsophagus is thrown into well-marked folds; there is a distinct groove, but little if any thickening of the mesogloea in this region.

Mesenteries.-The mesenteries have the usual macrocnemic arrangement. The imperfect mesenteries are distinct, although they extend but a short way into the body-cavity. The reflected ectoderm forms the mesenterial filaments in the usual way. The mesoglœa is not very well developed; both parieto-basilar and longitudinal muscles form almost simple layers. The endoderm is thinner than that of the body-wall, and contains in addition to the ordinary columnar cells, small oval cells which stain a very deep carmine.

Gonads.-No gonads were present in the specimens examined by us.

\section{PROBABLY BELONGING TO THIS GENUS.}

\section{Zoanthus rubricornis, Holdsworth.}

Zoanthus rubricornis:

Holdsworth, 1861, Proc. Zool. Soc.: and Ann. Mag. Nat. Hist. (3), vII., p. 484, woodcut. Hincks, 1861, loc. cit. (3), viII, p. 364.

Polythoa (Endeithoa) mbricornis:

Andres, 1884, Le Attinie, p. 316.

Form.-An unattached group of ten polyps, each gradually tapering from above downward, incrusted with sand; marginal serrations not nearly so conspicuous as in $E$, couchii. 
Colour.-Tentacles a distinct red.

Dimensions.-Largest polyp, $25 \mathrm{~mm}$. in height, and about 5-6 mm. diameter at the top when contracted. (Judging from the figure, $20 \mathrm{~mm}$. is the average height, and $5 \mathrm{~mm}$. the capitular diameter.)

Habitat.-Plymouth Sound.

This species has apparently never been met with since its discovery; and we are unable to do more than recast Holdsworth's description. We have no doubt that this species is an Epizoanthus; and it very closely resembles in outward appearance the specimens of $E$. couchii, which one of us has dredged off S.W. Ireland, the habit of growth being the most distinguishing feature, and upon this we do not place any reliance. Should this species be found to be distinct from E. conchii we expect that our Irish specimens would have to follow the former.

PARAZOANTHUS, n. g.

Macrocnemic Zoantheæ, with a diffuse endodermal sphincter muscle. The body-wall is incrusted. The ectoderm is continuous. Encircling sinus as well as ectodermal canals, lacunæ, and cell-islets in the mesoglœa. Diœcious. Polyps connected by thin cœnenchyme.

This is a very well marked genus anatomically; but it is often impossible to distinguish between certain species of this genus and those of Epizoanthus on external examination only.

We have taken for our type $P$. axinelloe (Schmidt), as this form is so readily obtainable, and, thanks to the Naples Zoological Station, is to be found in most museums. Another advantage is that it is one of the easiest of the incrusted Zoantheæ to study microscopically.

Erdmann was the first to separate the macrocnemic Zoantheæ, with a diffuse endodermal sphincter, from those with a mesogloal muscle. He rightly retained the genus Epizoanthus for the latter, but wrongly referred the former to Palythoa, of which he also took $P$. axinellae as the type. We have elsewhere (1891) entered into a detailed discussion of our reasons for restoring Palythoa to its type species $P$. mammillosa (E. \& S.), and we consequently have to erect the new genus defined above.

BRITISH SPECIES OF THE GENUS PARAZOANTHUS.

P. anguicoma (Norman), 1868.

$P$, dixoni, n. sp. 


\title{
SYNOPSIS OF BRITISH SPECIES OF PARAZOANTHUS.
}

\author{
(EXTERNAL CHARACTERS.)
}

Cœnenchyme thin, band-like, or inconsiderable; capitular ridges about 18, prominent, granulated, . . . . . . .

P. anguicoms.

Cœnenchyme thick, soft, expanded; capitular ridges about 21 ; not so prominent as in former,

\section{(ANATOMHOAL OHARACTERS.)}

Mesenteries project only a short distance from the body-wall into the colenteron ; endoderm of moderate thickness, uniform ; incrustations numerous, .

P. anguicoma.

Mesenteries project a considerable distance from the body-wall into the coelenteron; endoderm forming very thick ridges between every two mesenteries; incrustations few,

The following species is inserted for comparison with the above :-

Conenchyme thin, band-like or irregular expansions ; capitular ridges 13-15, not very prominent

Mesenteries much as in $P$. anguicoma; endoderm very thin and uniform; incrustations not very numerous, chiefly spicular, P. axinella (Mediterranean).

\section{Parazoanthus axinellæ (Schmidt).}

\section{Type species.-(Not British.)}

(Pl, LIx., fig. 8; Pl. Lx., figs. 6, 7.)

Palythoa axinella:

Schmidt, 1862, Spongien des Adriatischen Meeres, p. 61, pl. vI., figs. 2, 3. Gray, 1867, Proc. Zool. Soc., p. 238. Heller, 1868; Ber. k. zool., bot., Gesellsch., Wien, p. 21. Jourdan, 1880, Ann. des. Sci. Nat. (6), x., p. 43. Müller, 1883, Morphologie Palythoa u. Zoanthus, p. 8. Carus, 1884, Prod. Faunæ Medit., p. 76.

Zoanthus axinella:

Koch, 1880, Morph. Jahrb., vI., p. 359, pl. xvi., figs. 1-6.

Polythoa (str. s.) axinella:

Andres, 1884, Le Attinie, p. 311, pl. x., fig. 7.

Form.-Polyps obconical, coated with foreign particles; capitular ridges, 13-15, not very distinct. Tentacles, $26-30$; pointed with a very slight 
terminal swelling, perforated. Cœnenchyme band-like, linear, adhering to sponges; polyps usually in linear groups of three or four, sometimes solitary. Colour.-Yellowish.

Dimensions.-Height, $7 \mathrm{~mm}$; diameter, $3 \mathrm{~mm}$. ; tentacles, 5-10 mm. Habitat.-On various sponges, also on corallines and stones. Adriatic, Marseilles, Naples.

The foregoing description is compiled from the accounts given by Andres and Carus. In the specimens we have examined, as sent out by the Naples Zoological Station, we find that there is a considerable variation in the size of the polyps, some attaining a height of $13 \mathrm{~mm}$., and the cœenenchyme forms an irregular expansion on which the polyps are very crowded. The following anatomical account is based upon these specimens. We leave it for others to determine whether more than one species is commonly identified as $P$. axinelloe. Koch's specimens appear to be the same as ours, so far as his description and figures go. The Adriatic specimens require re-investigation.

Body-wall (Pl. LIX., fig. 8).-The body-wall is covered with a delicate cuticle, beneath which lies a rather thin layer of continuous ectoderm. Numerous oval nematocysts, which do not stain, are generally to be found among the granular and deeply staining columnar cells of the ectoderm. Incrustations, consisting for the most part of sponge spicules, are scattered, sometimes thickly, sometimes more sparingly, through the mesoglœa. Beneath these incrustations, separated from the endoderm by a thin layer of mesogloea, lies an encircling sinus, containing deeply staining nuclei and cell contents, as well as numerous nematocysts similar to those which are found in the ectoderm. The sinus is frequently interrupted by bars of mesoglœa of variable thickness, so that in cross section it often appears to consist of a circular series of rather narrow lacunæ. Canals frequently branch off from the sinus, and in many cases their connexion with the ectoderm can be distinctly seen. Single isolated cells are occasionally found enclosed in the mesoglœa. The endoderm forms a very thin and almost uniform layer.

Sphincter muscle.-The sphincter muscle is, as described by Erdmann, diffuse and endodermal.

Dise and Tentacles.--There is nothing worthy of special note in the structure of the disc and tentacles.

Esophagus.-The groove is well marked, and the mesogloea is considerably thickened in this region (Pl. Lx., fig. 6).

Mesenteries.-The arrangement of the mesenteries is macrocnemic. The imperfect mesenteries are well developed, often reaching nearly half way from the body-wall to the œesophagus. 'I'he longitudinal muscles are well developed in the upper part of the mesenteries, close to the dise, the fibres being supported in this 
region by well developed mesogloeal plaitings. Lower down the plaitings disappear, the muscles forming an almost simple layer. Close to the disc a bundle of transverse fibres are seen on the opposite side of each mesentery to that which bears the longitudinal fibres. These seem to be the prolongations of the endodermal muscles of the dise and tentacles. The reflection of the ectoderm of the osophagus, and its connexion with the filaments, can be well seen in this species (Pl. Lx., fig. 6). The mesogloea and the endoderm appear to be involved to some extent in the reflection also. The endoderm of the mesenteries forms, for the most part, a very thin layer, but it is much thickened in the region of the filaments (Pl. LX., fig. 7), the mesenteries in this region resembling those of Z. macgillivrayi (Pl. LxIV., fig. 8), but the thickening is not so marked as in that species, nor do we find here either zooxanthellæ or nematocysts.

Gonads.--In one of our specimens male gonads are present. They are surrounded by a thickened layer of endoderm (Pl. Lx., fig. 7).

\section{Parazoanthus anguicomus (Norm.).}

\section{(Pl. LVIII., figs. 34-36; Pl. LIX., figs. 11, 12.)}

Zoanthus sulcatus?:

Bowerbank, 1867, Proc. Zool. Soc., p. 351.

Zoanthus anguicoma :

Norman, 1868, "Shetland Report," Rep. Brit. Assoc., p. 319.

Polythoa (Taniothoa) anguicoma:

Andres, 1884, Le Attinie, p. 317.

Palythoa, sp. :

Ridley, 1886, Proc. Roy. Irish Acad. (2), rv., Sci., p. 617.

Palythoa anguicoma :

Hertwig, 1888, Suppl. "Challenger" Rep., Actiniaria, p. 46, pl. I., fig. 7. Is probably not $P$, anguicoma, but an allied species, $P$. hertwigi, n. $\mathrm{n}$.

Form.-Body rigid, rough; in some specimens the column has an almost warty appearance; capitular region swollen when contracted; radial ridges about 18 in number, prominent, rough. Tentacles in two cyles, of about 17 in each, very long and extensile, more than equal to diameter of dise when fully expanded; gradually attenuating to very slender points. Cœnenchyme incrusted, thin, either band-like. creeping on sponges and other objects, or forming broader expansions. The cœnenchyme is never well developed, and sometimes the polyps are isolated or in small groups. The smaller specimens, when contracted, have a button-like appearance.

Colour.--Pinkish-white (Norman); sand colour in preserved specimens. 
Dimensions.— "Column, 3-5 times as high as broad" (Norman). Height of column, when fairly extended (in spirit), $13 \mathrm{~mm}$.; diameter of withdrawn capitulum, $3-4 \mathrm{~mm}$. In the "button" condition the height is much less, about 4-5 mm., or even less. Some West of Ireland specimens have, in spirits, a height of $15 \mathrm{~mm}$., diameter of capitulum 5-6 mm., diameter of middle of column 3-4 mm.

Locality.-Shetlands, W. and S.W. Ireland. The exact localities for this species are as follows:- "Living on sponges, Phakellia ventilabrum and P. robusta, Normania crassa, Oceanapia jeffreysii, \&c., in very deep water, 110-170 faths., 20-25 miles N.N.W. off Burrafirth Lighthouse" (A.M.N.), (Pl. LviII., fig. 34); St. Magnus Bay, Shetland, 1867; "Porcupine, 1869, St. 8, 100-159 faths." [off Galway Bay, W. Ireland]. The foregoing are in Canon Norman's collection. 80 faths., 40 miles S.W. of Cape Clear, Co. Cork, 1885 (A.C.H.), (Pl. LvıI., fig. 36); 80 faths., off the Skelligs, Co. Kerry, July 13, 1886 (A.C.H.), (Pl. Lvin., fig. 35); 126 faths., off Achill, Co. Mayo, 1890 (A.C.H.).

This species is subject to considerable variation in general appearance, so much so that we at one time thought that the forms we had under review might belong to two species. This is the "squat button-like form" of Ridley (l.c.). There can be no doubt that this is the "Zoanthus sulcatus?-dispersed in patches on the surface of Desmacidon jeffreysii, from Shetland," of Bowerbank. Hertwig (1888, Suppl. "Chall." Rept. Actiniaria, pp. 446-48) doubtfully refers a colony of "Palythoa" to this species from Inaccessible Island, Tristan d'Acunha (S. Atlantic), 60-90 faths. From Erdmann's anatomical investigations of these specimens it is certain that they belong to the genus Parazoanthus. The species is certainly very close to $P$. anguicoma; but we consider that the slight differences in the external characters, together with the "considerable hollow expansion" of the encircling sinus ("ring-canal") invariably opposite the insertion of the mesenteries, are sufficient to separate the two species, and for the latter we would propose the name of Parazoanthis hertwigi.

Body-wall (Pl. LIx., figs. 11, 12).-The ectoderm, where present, is continuous, and is covered by a thin cuticle. It forms a layer of variable thickness, and consists of columnar cells containing deeply staining granules, and of oval nematocysts which do not readily stain. Incrustations, consisting of sand spicules, foraminifera, \&c., are fairly numerous, and are embedded both in the ectoderm and in the mesogloea. There is a well-developed encircling sinus, which lies beneath the incrustations. It is of variable thickness, and is frequently crossed by strands of mesoglœa; but these strands are not at all so thick as those in $P$. axinellee, and the sinus in consequence presents a much less broken appearance than in that species. Branching and anastomosing canals, very similar to those which we describe for $Z$. coppingeri (1891), connect the encircling sinus with the ectoderm. Nematocysts are frequently to be found in the encircling sinus. 
Cell-islets and lucunæ are also often enclosed in the mesogloea. The endoderm forms a thin layer of almost uniform thickness. The diffuse endodermal muscular layer is well developed.

Sphincter muscle.-The sphincter muscle is diffuse and endodermal, as in other species belonging to this genus. The mesoglœal plaitings are deep and well developed, but they branch very slightly.

Disc and Tentacles.-There is little worthy of special note in the structure of the disc and tentacles. The ectodermal muscles are exceedingly well developed.

Esophagus. - The ectoderm of the œsophagus is generally thrown into folds, but these are in some cases very slight. There is generally a well-marked groove, the mesogløa being here somewhat thickened. Occasionally cell-islets are to be found in this region.

Mesenteries. - The arrangement of the muscle is macrocnemic. The imperfect mesenteries generally extend well into the celenteron. The longitudinal muscles vary considerably in the degree to which they are developed, not only in individuals, but in different parts of the same individual. In some cases they form an almost simple layer, whilst in others they are supported on welldeveloped plaitings of the mesoglœa. The filaments are formed by the continuation of the ectoderm in the usual manner. Immediately below the œsophagus, the perfect mesenteries, bearing the filaments, extend but a short distance into the colenteron, leaving considerable empty space in the centre. Lower down they again increase in size, and near the base of the polyp they contain sinuses which appear to be of the same origin as the ectodermal enclosures of the body-wall.

Gonads.-There were no gonads in the specimens of this species which were examined by us.

\section{Parazoanthus* dixoni, n. sp.}

(Pl. LVIII., figs. 37, 38; Pl. LIx., figs. 9, 10 ; Pl. LX., figs. 8, 9.)

Form.-Body long, cylindrical, or quite short, smooth, or slightly roughened, very few incrustations. Polyps crowded, springing irregularly in all directions from an expanded, soft, thick coenenchyme. Buds often arise from close to the bases of the older polyps. Scarcely any diminution in the length of the contracted polyps is noticeable as compared with the expanded specimens. The upper end of the contracted specimens is swollen, and has about 21 inconspicuous

* We name this species in honour of our friends the brothers G. Y. and A. F. Dixon, who have done much valuable work in connexion with the Irish Actiniæ. 
radial ridges. Dise with distinct radii; mouth ellipsoidal, lips prominent. Tentacles in two cycles of about 21 in each; length about the diameter of the disc.

Colour.-Creamy white; polyps with a slight pinkish tinge.

Dimensions.-(In spirit). A. The larger specimens : height of column, $20 \mathrm{~mm}$; diameter, 4-5 mm. ; diameter of dise and tentacles, $10 \mathrm{~mm}$. ; the cœnenchyme of one colony measured $60 \mathrm{~mm}$. by $30 \mathrm{~mm}$. (Pl. LVIII., fig. 37). B. Medium specimens: height of column, $16 \mathrm{~mm}$; diameter, $3 \mathrm{~mm}$; average diameter of disc and tentacles, $9 \mathrm{~mm}$. C. Small variety: average height of column, $5 \mathrm{~mm}$. ; diameter, $4 \mathrm{~mm}$. (Pl. LVIII., fig. 38).

Locality.-West of Ireland (5-8 miles W. of the Great Skellig, Co. Kerry, 70-80 faths., July 13, 1886. A. C. H.). This species was also obtained by the "Porcupine" in 1869. (No locality. Norman collection).

Body-zvall (Pl. LIx., figs. 9, 10).-The ectoderm is continuous, and is covered by a thin cuticle. It forms a thick layer, consisting of very granular columnar cells, which stain deeply, and of numerous nematocysts which do not stain. The nematocysts in this species are scattered throughout the ectoderm in a fairly uniform manner. Incrustations consisting of spicules, grains of sand, and foraminifera may be found scattered at intervals through the mesoglœa, but in our specimens of the larger variety these are very rare. Beneath the incrustations lies a well-developed encircling sinus. It is frequently broken by strands of mesoglœa, and is connected with the peripheral ectoderm by numerous branching and anastomosing canals, very similar to those we find in $P$. anguicoma. The encircling sinus is connected with the endoderm by the fibrils or canalaculi of the mesoglœe, which are numerous and very distinct in our sections. The endoderm is not of uniform thickness as in $P$. anguicoma, but becomes very thick in the centre of each endocole and ectocœle, thus forming a longitudinal ridge between every two mesenteries. The diffuse endodermal muscular layer is well developed.

Sphincter muscle (Pl. Lx., fig. 8).-The diffuse endodermal sphincter is well developed, but very simple in character, the mesoglœea being raised into distinct but unbranched plaitings. In some sections some of these plaits appear to unite so as to enclose part of the muscle entirely in the mesoglœea, but we are uncertain whether this appearance is not due to the direction in which the sections are cut.

Dise and Tentacles.-.There is little worthy of note in the structure of the disc and tentacles. The ectodermal muscular layer is well developed.

Esophagns.-The ectoderm of the csophagus is thrown into deep folds, into which the mesogloea also enters. There is a deep, well-marked groove, and the mesogloea is here very much thickened.

Mesenteries.-The arrangement of the mesenteries is macrocnemic. The imperfect mesenteries are well developed, and extend into the body-cavity nearly half-way between the body-wall and the oesophagus. The ectoderm of the 
œsophagus is comnected with the filaments in the usual manner. The mesogloea of the mesenteries is well developed in all our specimens, and is thickened as well as raised into distinct plaitings on that side of each mesentery which bears the longitudinal muscle fibres (PI. LX., fig. 9). The parieto-basal muscles are not so well developed as the longitudinal ones; and they extend along each side of the mesenteries, but a short way into the cœlenteron; there is therefore no difficulty in distinguishing between the two sets of muscles; and the pairing of the mesenteries can be very distinctly seen in this species. The endoderm of the mesenteries is thinner than that of the body-wall. The perfect mesenteries, from the termination of the œsophagus downward, extend far into the celenteron, which is, in consequence, almost filled up by the mesenteries and their filaments. Transverse sections of $P$. dixoni, taken just below the œsophagus, present in consequence a very different appearance from those of $P$. anguicoma taken from the same region. In our specimens of the small variety we find well-marked sinuses in the mesogloea of the mesenteries, extending from the conenchyme a short distance upward into the cœlenteron, disappearing at about the lower termination of the mesenterial filaments. These sinuses are very similar in appearance to the ectodermal sinuses of $Z$. coppingeri, but we are unable to find in them any connexion with the ectodermal canals of the body-wall, whilst in several places they appear to be distinctly connected with the endoderm. We do not find these sinuses in the mesenteries of any of those specimens of the larger variety of $P$. dixoni which we have cut.

Gonads.-We have found no gonads in our specimens of this species.

\section{OF UNCERTAIN POSITION.}

Zoanthus sulcatus, Gosse.

Zoanthus sulcatus:

Gosse, 1860, Brit. Sea Anemones, p. 303, pl. Ix., fig. 7; pl. xIr., fig. 2 . Hincks, 1861, Ann. Mag. Nat. Hist. (3), vIII., p. 364.

Gemmaria (?) sulcata:

Gray, 1867, Proc. Zool. Soc., p. 238.

Pulythoa sulcata:

Fischer, 1874, Nouv. Arch. Mus. Paris, pp. 286, 239 ; 1874, Comptes rendus, LxxIx., p. 1207 (trans. Ann. Mag. Nat. Hist. (4), xv., p. 374); 1875, Actes Soc. linn. Bordeaux, xxx., p. 8 ; 1887, Arch. Zool. exp. gén. (2), v., pp. 435, 487. Jourdan, 1890, Bull. Soc. Zool., xv., p. 175. Polythoa (Taniothoa) sulcata:

Andres, 1884, Le Attinie, p. 317. Pennington, 1885, Brit. Zooph., p. 183.

Form.-Column generally cylindrical, but versatile; upper third of extended column free from sand, and indented with twenty-two longitudinal sulci; lower portion sparsely incrusted with very fine sand. Disc saucer-shaped. Tentacles, 
42 , in two rows, the inner row corresponding in position to the marginal teeth, the outer intermediate; sub-equal, conical, pointed, usually radiating horizontally. Cœnenchyme band-like, often bearing three polyps abreast, loosely invested with coarse sand.

Colour.-Column dull uniform olive, each intersulcus having a blackish spot near its summit; each tooth is silvery white. Disc olive-yellow; tentacles colourless, transparent, with yellow-brown pigment granules.

Dimensions.-Column about $3 \mathrm{~mm}$. high, and about $2 \mathrm{~mm}$. wide.

Locality.-Torbay, on rock, between tidemarks.

Hincks (l.c., p. 364) says:- "Mr. Gosse mentions a single colony of this pretty but very minute species as having occurred to him at Broadsands, near Brickham, on sandstone rock. On the opposite side of Torbay, however, and very close to Torquay, I have found it abundantly in the small basins hollowed out in the limestone. The Zoanthus forms little colonies on the floor of these miniature pools ; but they may readily be passed over as tufts of some minute weed." Mr. G. Y. Dixon informs us that he has carefully hunted over the rock where Gosse obtained his original specimens, without being able to re-discover this species.

Fischer (1874, p. 236) describes this species as follows:- "Column covered in its superior half with very fine and agglutinated sand, uniformly brownish or olive, with 22 rays or ridges, on which one sees grains of sand arranged in vertical lines. The superior border of the column is indicated by a dentate border; the teeth are 11 in number, and their colour is white. The disc of the same colour as the column appears rayed. The tentacles to the number of 22 are arranged in two rows; the 11 tentacles of the inner row are longer than the marginal by a third or a fourth. They are conical, transparent, ornamented with some brown spots; their extremities have an opaque white colour. The yellow mouth is not prominent."

"I have found this species at the landing place of Arcachon, at the limit of low tide; it forms very numerous colonies, which have an appearance of the perforating sponges (Cliona), but their colour is more pronounced. The colony is fixed upon an expansion thickened by sand and other adherent matter. This is perforated by circular holes for the emission of the Zoantheæ, which sink in and disappear when they are disturbed. M. Lafont has met with this species at Guéthary, on rocks.

"The figure given by Mr. Gosse is very bad. . . . The small size, the colour, the habitat of this species, readily distinguish it from the preceding [E. couchii]. When it is extended it measures $4 \mathrm{~mm}$. in diameter." - It occurs between tides (littoral zone), p. 239. The other Papers are merely abstracts.

Later (1887), Fischer gives the following French localities:-"Le Croisic, Piriac (Région armoricaine); Arcachon, Guéthary, (Région aquitanique); Zone littorale," p. 435. 
Jourdan has recently (1890, p. 175) identified a form dredged by the Prince of Monaco (? either from the Bay of Biscay or off the Azores) as "Palythoa sulcata Gosse."

\section{Zoanthus alderi, Gosse.}

Zoanthus alderi:

Gosse, 1860, Brit. Sea Anemones, p. 305, pl. ix., fig. 8 ; pl. xir., fig. 5. Gray, 1867, Proc. Zool. Soc., p. 234. Pennington, 1885, Brit. Zooph., p. 183. Alder, Trans. Tyneside Nat. Fiold Club, v.

Zoanthus (Rhyzanthus) alderi:

Andres, 1884, Le Attinie, p. 328.

Form.- "Polyp inversely conical, the summit being two or more times as broad as the base ; summit (in the button state) swelling, flat, depressed in the centre, with many (about twenty?) radiating strix, indicating the marginal teeth. Surface smooth, without any investment of sand, but marked throughout with close-set, transverse, or annular wrinkles. Cœnenchyme narrow, smooth, irregularly branching, free from sand."

Colour.-Opaque, milk-white.

Dimensions.-Height of column about two lines $(4 \mathrm{~mm}$.); greatest diameter about half a line $(1 \mathrm{~mm}$.).

Habitat.-Northumberland; under-surface of a stone, at extreme low water, near the "Bear's Rock," Cullercoats (Alder).

This species has not been met with since its first discovery by J. Alder in 1857 . Gosse says: "There were about a dozen polyps in the colony, all of the same size, which seems to be good evidence that they had attained adult dimensions." Alder adds that he has "searched for it several times without success." We cannot help regarding this as an immature form.

No representative of the genus Zoantha, as determined by anatomical investigation, is known to occur in the extra-tropical portion of the North Atlantic.

Until the anatomy of " $Z$. rubricornis," " $Z$. sulcatus," and " $Z$. alderi" is investigated it will be impossible to tell the genus, let alone the species. The same criticism applies to the identification of nearly all the Zoantheæ. 


\section{BIBLIOGRAPHY OF THE ZOANTHEE.}

1767. Elils, J. :

An account of the Actinia sociata, \&c. (Phil. Trans. Roy. Soc., LVII., pt. i. (1768), p. 428, pl. xix.)

1786. Eluts, J., and Solander, D. :

The Natural History of many curious and uncommon Zoophytes. London, pls.

1798. Cuvrer, G. C. L. D. :

Tableau élémentaire de l' Histoire naturelle des Animaux. (Ann. 6, Journ. de Phys., xuvi., pp. 370-384.)

1801. Lamarce, J. B. :

Système des Animaux sans Vertèbres. Paris.

1802. Boso, $\mathrm{I}_{\mathrm{d}}$ :

Histoire naturelle des Vers. Suites a Buffon. Castel, Paris.

1816. Lamouroux, J. V. F. :

Histoire générale des Polypiers coralligènes flexibles. Caen.

1817. Cuvier, G. C. L. D. :

Règne animale, Iv.

1817. Lesueur, C. A. :

Observations on several species of the Genus Actinia. Illustrated by figures. (Journ. Acad. Nat. Sci. Philadelphia, I., pp. 149, 169, pls. vii., viii.)

1821. Lamouroux, J. V. F.:

Exposition méthodique des genres de l'ordre des polypiers avec leur description et celle des principales espèces figurées dans 84 planches; les 63 premières appartenant a' l'histoire naturelle des Zoophytes d' Ellis et Solander. Paris.

1828. GraY, J. E. :

Spicilegia Zoologica, pls. 
1830. LESSON, R. P. :

Zoologie. Voyage autour du monde sur la corvette de S. M. la Coquille, pendant les années 1822-1825, par L. J. Duperrey. Paris, 1828, pls.

1832. Delle Chuje, S. :

Istituzioni d' Anatomia comparata. Napoli, pls., (edition 2, 1836).

1833. Quox et Gamard :

Zoologie du Voyage de la corvette l'Astrolabe, pendant les années 1826-1829, by G. Dumont d'Urville. Paris, 1830, pls.

1884. Ehrenberg, C. G. :

Beiträge zur physiologischen Kenntniss der Korallenthiere im Allgemeinen und besonders des Rothen Meeres nebst einem Versuche zur physiologischen Systematik derselben. (Abhandl. d. König. Akad. d. Wissensch., Berlin, 1832, p. 225.) [Published in 1834, and also as a separate volume, Die Korallthiere des Rothen Meeres.]

1834. Johnston, G. :

Illustrations in British Zoology. Spongia suberia. (Loudon's Mag. Nat. Hist., vi., p. 491, fig. 60).

1834. Blatnvilue, H. M. DE :

Manuel d' Actinologie ou de Zoophytologie, with Atlas. Paris.

1836. Lamarck, J. B. :

Histoire des Animaux sans Vertèbres. [Deshayes and Milne Edwards' revised and augmented edition.]

1838. Couch, J. :

A Cornish Fauna, being a Compendium of the Natural History of the County. London.

1842. JohNSTON, G. :

History of British Sponges and Lithophytes, pls. and woodeuts. Edinburgh.

1843. Thompson, W. :

Report on the Fauna of Ireland, div. Invertebrata. (Brit. Assoc. Rep., p. 245.)

1844. Thомpson, W. :

Additions to the Fauna of Ireland. (Ann. Mag. Nat. Hist., xur., p. 430.)

1844. Forbes, E. :

Notice of some additions to the British Fauna discovered by Robert Mac Andrew, Esq., during the year 1844. (Ann. Mag. Nat. Hist., xiv., p. 415.)

1845. LANDSBoRoUGH, D. :

Notice of some Rarities found on the West Coast of Scotland. (Ann. Mag. Nat. Hist. (1), xv., p. 327.) 
1846. Dana, J. D. :

Report on Zoophytes, U. S. Explor. Exped., 1838-1842, with Atlas.

1847. JoHnston, G. :

A History of British Zoophytes, vol. i., vol. ii, pls., 2nd edit. [The one which is always used.]

1847. Düben, M. W., And Koren, J. :

Om. nogle norske Actinier. (Forhandl. Skan. Naturf. Möde, p. 266.)

1848. Düben, M. W., ANd KoRen, J. :

Ueber einige norwegische Actinien. Isis, p. 536.

1851. SARS, M. :

Beretning om en i Sommeren 1849, foretagen zoologisk Reise i Lofoten og Finmarken. (Nyt Mag. Naturvid., vr. (2), p. 122.)

1851. Le CONTE, J. L. :

Zoological Notes. New species of . ... Zoantha. (Proc. Acad. Nat. Sci. Philadelphia, v., p. 320.)

1856. Thonpson, W.:

The Natural History of Ireland. (London, 1849-1856, vol. iv., 1856.)

1856. SteEnstrup, J. J. S. :

Kongelige Danske Videnskab. Selskabs. Forhandl.

1857. MunNe-Edwards, H. :

Histoire naturelle des Coralliaires, ou Polypes proprement dits, I., with atlas. Paris.

1858. Gray, J. E. :

On the Dysidea papillosa of Dr. Johnston. (Proc. Zool. Soc., 1858, p. 531, pl: x., fig. 8, of separate vol., "Radiata "). [Sidisia barleci, g. and sp. nn.]

1858. HoLdsworth, E. W. H. :

On Zoanthus couchii, Johnston. (Proc. Zool. Soc., 1858, p. 557, pl. x., figs. 3-7.)

1858. Wright, E. P., and Greene, J. R. :

Report on the Marine Fauna of the South and West Coasts of Ireland. (Brit. Assoc. Rep., p. 176.)

1858. GRAT, J. E. :

Note on Dysidea papillosa, Johnston. (Ann. Mag. Nat. Hist. (3), II., p. 489.)

1859. DaNIELSSEN, D. C. :

Beretning om en zoologisk Reise foretagen i Sommeren 1857. (Nyt Mag. Naturvid., x (1861), p. 1.)

TRANS. ROY. DUB. SOC., N.S. VOL. IV., PART XII. 
1859. HozDsworth, E. W. H. :

On Zoanthus couchii, Johnston. (Ann. Mag. Nat. Hist. (3), Iv., p. 152.)

1860. SARS, M. :

Oplysninger om nogle Cœlenterater fra Norges Kyster. (Forhandl. Skand. Naturf. Möde. Kjöbenhavn, vIII., p. 690.)

Om nogle nye eller lidet bekjendte norske Cœlenterater. (Forhandl. Vidensk. Selsk. Christ.)

1860. Gosse, P. H. :

Actinologia Britannica: A History of the British Sea Anemones and Corals. London. [Part xI., pp. 321-352, which contains the Zoantheæ, was published in Nov., 1859.]

1860. Duchassatng, P., et Michelotti, J. :

Mémoire sur les Coralliaires des Antilles. (Mem. Reale Accad. Sci., Turin (2), xrx. (1861), p. 279, pls.)

1861. Holdsworth, E. W. H. :

On an Undescribed species of British Zoanthus. (Proc. Zool. Soc., 1861, p. 99; also in Ann. Mag. Nat. Hist. (3), vII., p. 484, fig.) [Z. rubricornis, n. sp.]

1861. HincKs, T. :

Catalogue of the Zoophytes of South Devon and South Cornwall. (Ann. Mag. Nat. Hist. (8) vIII., p. 364.)

1862. Alder, J. :

Supplement to a Catalogue of the Zoophytes of Northumberland and Durham. Trans. Tyneside Nat. Field Club, v., pt. iii.) [Vol. v. runs from 1861-1863.]

1862. Кснмшт, О. :

Spongien des Adriatischen Meeres. Leipzig, pls.

1864. VerRILL, A. E. :

Revision of the Polypi of the Eastern Coast of the United States. (Mem. Boston Soc. Nat. Hist., I. (read 1862, published 1864), p. 1, pls.)

1866. Verrill, A. E.:

On the Polyps and Echinoderms of New England. (Proc. Boston Soc. Nat. Hist., x., p. 333.)

1866. Duchassatig, P., ex Mrohelotti, J. :

Supplément au Mémoire sur les Coralliaires des Antilles. (Mem. Reale Accad. Sci., Turin (2) хxiI., p. 97, pls.)

1867. BoWeraANB, J. S. :

Additional Observations on Hyalonema mirabile. (Proc. Zool. Soc., p. 350.) 
1867. Gray, J. E. :

Notes on the Zoanthinæ, with Descriptions of some New Genera. (Proc. Zool. Soc., 1867, p. 233, woodcut.) [Brit. sp. referred to-Zoanthus alderi; Sidisia barleei; Epizoanthus, n. g. ; E. papillosus; Gemmaria (?) sulcata; Carolia, n. g. ; C. couchii.]

1868. HELLER, C. :

Die Zoophyten und Echinodermen des Adriatischen Meeres. (Ber. k. zool. bot. Gesellsch,, Wien.)

1868. Norman, A. M. :

Last Report on Dredging among the Shetland Isles. (Brit. Assoc. Rep., p. 232.)

1869. VERRILL, A. E. :

Notes on Radiata. Review of the Corals and Polyps of the West Coast of America. (Trans. Connect. Acad,; I., 1867-1871, p. 377 (p. 495, Mar., 1869).)

1872. DANA, J. D. :

Corals and Coral Islands.

1873. VERRTL, A. E. :

Report upon the Invertebrate Animals of Vineyard Sound and the Adjacent Waters, with an Account of the Physical Characters of the Region. Iv., 5, Fauna of the Muddy Bottoms off the open Coast. (Report of the United States Commissioner of Fish and Fisheries, 1873 , pp. 295-747, pls. I. to xxxvIII.)

1874. Fisoher, P. :

Sur les Actinies des côtes océaniques de France.; (Comptes rendus, Lxxxrx., p. 1207; translated in Ann. Mag. Nat. Hist. (4), xv., 1875, p. 373.)

1874. Fischer, P.:

Recherches sur les Actinies des côtes océaniques de France. (Nouv. Arch. du Muséum, Paris, x., p. 193.) [The title page of the vol. gives 1874, but Dr. Fischer (1887) and other authors give the date as 1875.]

1874. SMith, S. J., AND Harger, O. :

Report on the Dredgings in the Region of St. George's Banks in 1872. (Trans. Connect. Acad., III., p. 1, pls.)

1875. Martens, E. von:

Ueber Palythoa. (Sitzungesber. Gesell. Naturf. Freunde. Berlin, p. 21.)

1875. FisCHeR, P. :

Anthozoaires du département de la Gironde et des côtes du sud-ouest de la France. (Actes Soc. linn. Bordeaux, xxx., p. 183.)

1877. Andres, A. :

On a New Genus and Species of Zoanthina malacodermata [Panceria spongiosa, sp. n.] (Quart. Journ. Micr. Sci. (N. S.), 1877, p. 221 pl. xrr.) 
1877. KLUnzinger, C. R. :

Die Korallthiere des Rothen Meeres, I. Alcyonarien und Malacodermen. Berlin.

1878. STUDER, T. :

Zweite abtheilung der Anthozoa polyactinia, welche während der Reise S. M. S. Corvette Gazelle um die Erde gesammelt werden. (Monatsber. Königl. preuss. Akad. Wissensch. Berlin, p. 524, pl.)

1880. KocH, G. voN :

Notizen über Korallen. (Morph. Jahrb., vi., p. 355, pl. xvr.)

1880. Jourdan, E. :

Recherches zoologiques et histologiques sur les Zoanthaires du Golfe de Marseille. (Ann. des Sci. Nat. (6), x., p. 1.)

1882: VerRILL, A. E. :

Notice of the remarkable Marine Fauna occupying the outer banks of the Southern Coast of New England, No. 3. (Am. Journ. Sci. (3), xxir., p. 135 ; ibid., No. 5, p. 309.)

1882. Hertwig, R. :

Report on the Actiniaria dredged by H. M. S. "Challenger". during the years 1873-1876. (The Zoology of the Voyage of H. M. S. "Challenger," pt. xv., 1882, pls. Supplement, $1888, \mathrm{pls}$.

1882. Marion, A. F. :

Actiniaires atlantiques des dragages de l'aviso le Travailleur. (Compt. rend., xcrv., p. 458; translated in Ann. Mag. Nat. Hist. (5), Ix., p. 334.)

1883. VerRILL, A. E. :

Report on Anthozoa and on some additional Species dredged by the "Blake," in 1877-1879, and by U. S. Fish Commission Steamer "Fish Hawk" in 1880-1882. (Bull. Mus. Comp. Zool. Cambridge, Mass., జr., 1883-1885.)

1883. MÜLler, G. :

Zur Morphologie der Scheidewände bei einigen Palythoa und Zoanthus. Marburg. [Dissertation for Doctor's degree privately printed.]

1884. CARUS, J. V. :

Prodromus Faunæ Mediterraneæ. Stuttgart.

1884. ANDREs, A. :

Le Attinie. (Fauna u. Flora d. Golfes v. Neapel, Ix. Leipzig.) [Published in the Atti. R. Accad. dei Lincei, Rome (3A), xIV., 1883.]

1884. VerriLL, A. E. :

Notice of the remarkable Marine Fauna occupying the outer banks off the Southern Coast of New England, and of some additions to the Fauna of Vineyard Sound. (Am. Fish. Com. Rep. for 1882, p. 641.) [Partial reprint of Verrill, 1882.] 
1885. VerRILL, A. E. :

Results of the Explorations made by the steamer "Albatross" off the Northern Coast of the United States in 1883. (U. S. Fish. Commission Report for 1883, p. 503, pls.)

1885. Pennington, A. S. :

British Zoophytes : an Introduction to the Hydroida, Actinozoa, and Polyzoa found in Great Britain, Ireland, and the Channel Islands ; with plates. London.

1885. Erdmann, A. :

Ueber einige neue Zoantheen. Ein Beitrag zur anatomischen und systematischen Kenntniss der Actinien. (Jenaische Zeitschr. Naturwiss., xIx., p. 430, pls.)

1886. KосH, TV. :

Neue Anthozoen aus dem Golf von Guinea. Marburg, 36 pp., 5 pls.

1886. RiDley, S. O. :

Zoanthidæ-First Report on the Marine Fauna of the South-West of Ireland. (Proc. Roy. Irish Acad. (2), Iv., Sei., p. 599.)

1887. FisOHer, P.:

Contribution à l'Actinologie française. (Arch. Zool, exp. et. gén. (2), v., p. 381.)

1888. HERTWIG, R. :

Supplementary Report. (See 1882.)

1889. HADDON, A. C. :

A Revision of the British Actiniæ, pt. I. (Trans. Roy. Dubl. Soc. (2), rv., p. 297, pls.)

1889. Fischer, P. :

Nouvelle contribution à l'Actinologie française: $1^{\text {e }}$ partie, Actinies d'Arcachon; $2^{\text {e }}$ partie, Actinies de Guéthray. (Actes. Soc. linn. Bordeaux, xrm., p. 252.)

1889. M'Murrich, J. Playfatr :

A Contribution to the Actinology of the Bermudas. (Proc. Acad. Nat. Sci., Philadelphia, p. 102, pls. vI., vII.)

1889 a. M M Murrich, J. Playfair :

The Actiniaria of the Bahama Islands, W. I. (Journal of Morphology, II., p. 1, pls. I.-IV.) [The latter Paper was. written before the former, though it was published slightly subsequently to it.]

1890. Danielssen, D. C. :

Actinidæ. (The Norwegian North Atlantic Expedition, 1876-1878. Zoology. pls.)

1890. Bourne, G. C. :

Report of a Trawling Cruise in H. M. S. "Research" off the South-West of Ireland. (Journal Marine Biological Association (Plymouth), I., p. 306.) 
1890. JoURdan, E.:

Note préliminaire sur les Zoanthaires provenant des Campagnes du Yacht 1' Hirondelle, 18861888. (Bull. Soc. Zool. Paris, xv, p. 174.)

1890. Beneden, E. VAN :

Les Anthozoaires pélagiques recueillis par M. le Prof. Hensen dans son Expéd. du Plankton.

1. Une Larve voisine de la Larve de Semper. (Bull. Acad. roy. Belgique (3), xx., p. $55, \mathrm{pl}$.)

1891. MMurrich, J. Peayfatr:

Contributions on the Morphology of the Actinozoa. III. The Phylogeny of the Actinozoa. (Journal of Morphology, v., pp. 125-164, pl. Ix.)

1891. Haddon, A. C., and Shackleton, A. M. :

Actiniæ.-I. Zoantheæ. Reports on the Zoologieal Collections made in Torres Straits by A. C. Haddon, 1888-1889. (Trans. Roy. Dubl. Soc., vol. rv., ser. ii., pt. xir.) 


\section{INDEX OF GENERA AND SPECIES.}

CAROLIA = EPIZOANTHUS, 634.

couchii, 645 .

\section{CORTICIFERA = PALYTHOA.}

lutea, 631.

DXSIDEA = EPIZOANTHUS, 634.

papillosa, 634, 636, 645 .

ENDEITHOA (? genus).

rubricornis, 652 .

EPIZOANTHUS, 632, 634.

abyssorum, 633, 638, 639 .

americanus, $615,632,636,638,639,640$.

arenaceus, $619,632,637,639,649$.

cancrisocius, $632,633,636$.

couchii, 616, 618, 619, 632, 635, 637, 644, $645,646,647,649,653,661$.

- var. linearis, 645 .

elongatus, 633.

erdmanni, $623,633,635,639$.

eupaguri, 633.

incrustatus, 615, 616, 618, 619, 622, 627, $632,634,635,636,639,648$.

macintoshi, 615, 625, 633, 635, 649, 650, 651.

norvegicus, $614,632,650,651$.

paguriphilus, $611,614,615,616,620,622$, $633,635,641,643$.

papillosus, 632, 634, 636 .

parasiticus, 633 .

stellaris, 633 .

thalamophilus, 633 .

wrightii, 614, 615, 616, 633, 635, 651.
GEMIMARIA, 630.

isolata, $621,627,630$.

macmurrichi, $614,616,617,630,643$.

mutuki, 617, 630 .

philippinensis, 630 .

rusei, $621,626,627,630$.

sulcata, 660 (? genus).

ISAURUS, 630 .

asymmetricus, $616,617,618,621,622,623$, 630.

cliftoni, 630 .

spongiosus, 630 .

tuberculatus, 617, 621, 623, 626, 630 .

IIAMMILLIFERA, 630, 634 .

auricula, 626, 630 .

conferta, 629 (=Zoanthus confertus).

incrustata, 636 (= Epizoanthus incrustatus).

nуmphæa, 630 .

tuberculata, 617, 621, 623 (= Isaurus tuberculatus).

\section{IARDQELL = EPIZOANTHUS.}

erdmanni, 623,635 .

PALYTHOA, 631, 634.

aggregata, 631 .

anguicoma, 656 (Parazoanthus).

arenacea, 636, 645, 649 (= Epizoanthus arenaceus).

argus, 631 .

axinellæ, 617, 654 (Parazoanthus).

calcaria, 631.

caribæorum, 631 .

cinerea, 631 . 
PAIYTHOA-(continued).

coesia, 631 .

cosia?, 619, 631 .

couchii, 645 (Epizoanthus).

flava, 631 .

flavo-viridis, 631 .

glareola, 631 .

glutinosa, 631 .

howesii, $617,618,622,623,625,631$.

kochii, $617,618,622,623,631$.

lutea, 631 .

mammillosa, 626, 631, 653 .

ocellata, 631 .

sulcata, 660 (? genus).

tuberculosa, 631 .

sp., 656 .

PARAZOANTHUS, 633, 653.

anguicoma, 615, 616, 617, 619, 621, 622, $633,653,654,656,657,659,660$. axinellæ, 611, 615, 617, 620,622, 627, 633, $653,654,655,657$.

dichroicus, 615, 617, 619, 622, 625, 633 . dixoni, 614, 615, 616, 617, 619, 620, 621, $622,633,653,654,658$.

douglasi, 615, 617, 619, 624, 625, 633.

hertwigi, $616,633,657$.

sp., 633 .

POLYTHOA = PALYTHOA (pars), and PARA-

ZOANTHUS (pars), 634.

anguicoma, 656 (Parazoanthus).

arenacea, 636, 645, 649 (= Epizoanthus arenaceus).

axinellæ, 654 (Parazoanthus).

incrustata, 636 .

rubricornis, 652 (? genus).

sulcata, 660 (? genus).
RHYZANTHUS (? genus).

alderi, 662 .

SIDISIA = EPIZOANTHUS, 634 .

barleei, $632,634,636,638$.

SPHENOPUS, 632.

arenaceus, 632.

marsupialis, 626, 632 ; var. bursiformis, 632 . pedunculatus, 632 .

SPONGIA = IPIZOANTHUS, 634.

suberia, 636 .

TENIOTHOA (? genus). sulcata, 660 .

ZOANTHUS, 629, 634 .

alderi, 662 (? genus). anguicoma, 656 (Parazoanthus). axinellæ, 654 (Parazoanthus).

coppingeri, 616, 618, 621, 622, 623, 629, $643,657,660$.

confertus, 629 .

couchii, 636, 637, 638, 644, 646 (Epizoanthus).

danæ (?), 616, 620, 623, 629 .

danai, 629.

flos-marinus, 621, 622, 629.

incrustatus, 636, 638 (Epizoanthus).

julkesii, $616,618,620,621,623,629$.

macgillivrayi, 618, 620,621, 622, 623, 625, 629,656 .

paguriphilus, 641 (Epizoanthus).

rubricornis, 652 (? genus).

sociatus, 621, 626, 629 .

sulcatus, $656,657,660$ (? genus).

sp., 623,629 . 
EXPLANATION OF PLA'TE LVIII. 


\section{P L A T E L VIII.}

Fig.

1-22. Epizoanthus incrustatus (Düb. \& Kor.), (p. 636).

1-11. Free variety from Shetland; Nus. Normani-1, simple form, with two polyps; 2-4, $5-8,9-11$, three varietal series.

12-13. Typical incrusting forms from Shetland; Mus. Normani.

14-21. Incrusting forms from Galway Bay. These are rather smaller and darker than the more usual forms. This series, starting from a single polyp, illustrates the manner in which new polyps arise.

22. Antero-posterior section of a carcinæcium, to show the position of the polyps and the absence of a ventral polyp.

All the above are drawn from spirit specimens, and are natural size.

23-25. Epizoanthus paguriphitus, Verr. (p. 641).

23-24. Upper and under surface of two different specimens from off S.-W. Ireland; half natural size.

25. Young specimen from W. of Ireland; natural size; $p . p$. posterior polyp.

26-28. Epizoanthus couchii (Johnst.), (p. 644).

26. Living specimen from Berehaven; drawn by A. C. H.

27-28. Spirit specimens from S.-W. Ireland; all natural size.

29. Epizoanthus macintoshi, n. sp. (p. 649).

Spirit specimen from Shetland; natural size.

30-33. Epizoanthus wrightii, n. sp. (p. 651).

30-32. Living specimens from Dublin Bay; drawn by Mr. G. Y. Dixon; not to scale. 32 showing larræ swimming inside the tentacles.

33. Spirit specimen; natural size.

34-36. Parazoanthus anguicoma (Norm.), (p. 656).

34. Some of the original type specimens, consisting of one isolated example, and a group of four polyps on a sponge, from Shetland (the specimen has unfortunately dried up); Mus. Normani.

35. Ordinary forms from S.-W. Ireland, on the tube of a Serpula.

36. Button-like variety, on the tube of a Hyalonœeia; both natural size, from spirit specimens.

37-38. Parazoanthus dixoni, n. sp. (p. 658).

37. Group of living specimens from S.-W. Ireland; tall variety; drawn by A. C. H.

38. Short variety; spirit specimens all natural size.

[All the above specimens are in the British Museum, excepting Nos, 1-13 and 34. No. 29 was presented by Prof. W. C. M'Intosh, and No. 33 by Mr. G. Y. Dixon.] 
Trans.R.Dub.S.N.S.Vol.IV.

Plate LVIII.

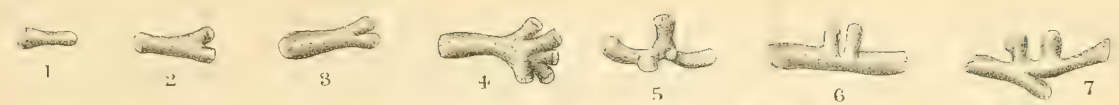

$A^{2} \mathrm{y}$, wh th

क :

$1+$

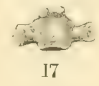

$\underbrace{01}_{18}$

$+5 \frac{2}{2}$
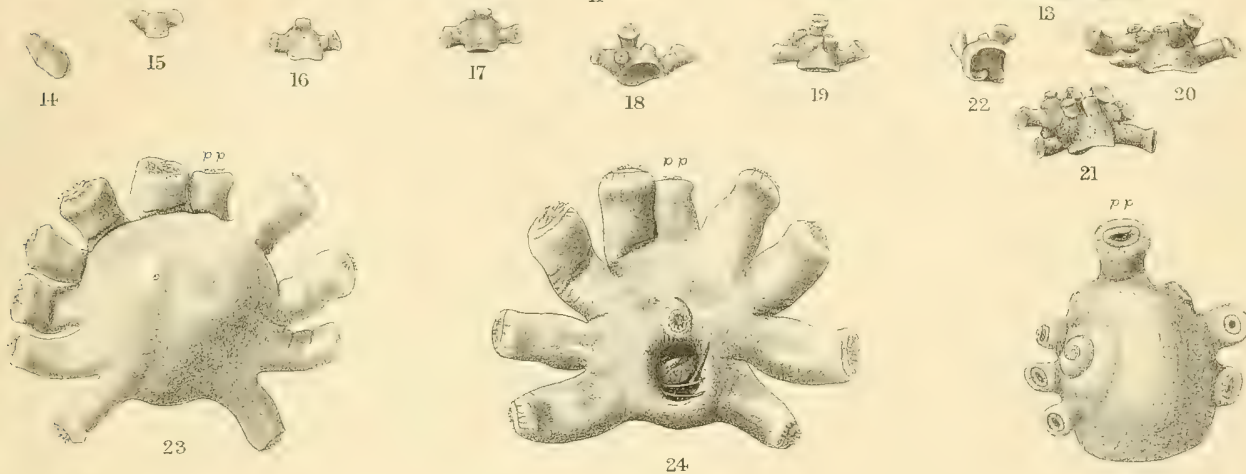

21

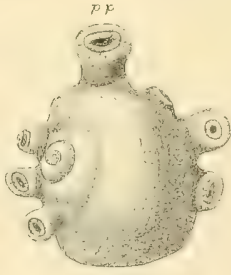

25
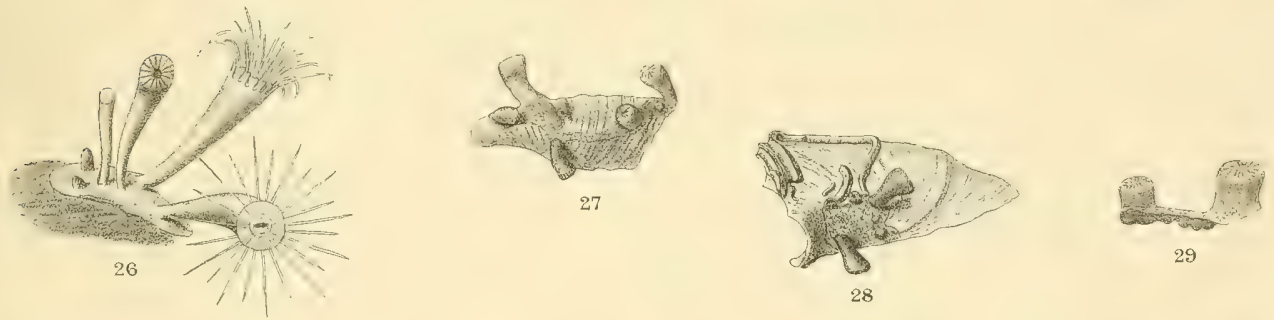

29

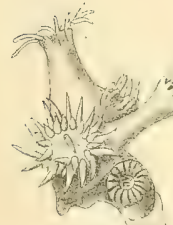

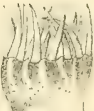

30

31
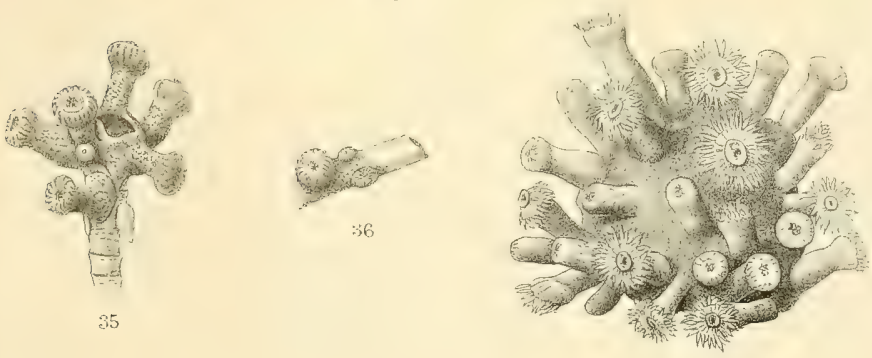

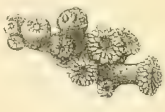

33

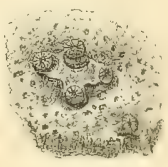

34 




\section{PLATE L IX.}

\section{LETTERING ADOPTED IN THE FIGURES.}

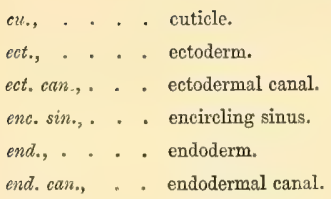

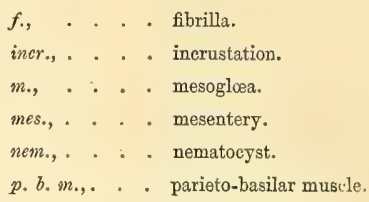

Fig.

1. Epizoanthus macintoshi, n. sp. (p. 649). Transverse section through the body-wall, $\frac{2}{B}$.

2. Episoanthus incrustatus (Düb. \& Kor.), (p. 636). Transverse section through the body-wall, $\frac{2}{B}$.

3. Episoanthus wrightii, n. sp. (p. 651). Transverse section through the body-wall, $\frac{2}{B}$.

4. Epizoanthus cowchii (Johnst.), (p. 644). Transverse section through the body-wall, $\frac{2}{B}$.

5. Epizoanthus norvegious (Kor. \& Dan.), (p. 650). Transverse section through the body-wall, $\frac{2}{B}$.

6. Epizoanthus paguriphilus, Verr. (p. 641). Transverse section through the body-wall, $\frac{2}{A}$.

7. Epizoanthus arenacous (D. Ch.), (p. 649). Transverse section through the body-wall, $\frac{2}{B}$.

8. Parasoanthus axinelle (Schmidt), (p. 654). Transverse section through the body-wall, $\frac{2}{B}$.

9. Parasoanthus dixoni, n. sp. (p. 658). Vertical section through the body-wall, $\frac{2}{B}$.

10. Parazoanthus dixoni. Transverse section through the bolly-wall, $\frac{2}{B}$.

11. Parazoanthus anguicoma (Norm.), (p. 656). Transverse section through the body-wall, $\frac{2}{B}$.

12. Parazoanthus anguicoma. Vertical section through the body-wall, $\frac{2}{B}$.

* These letters of magnification refer in all cases to Zeiss' system. 


\section{Trans.R.Dub.S.,N.S.,Vol.IV.}

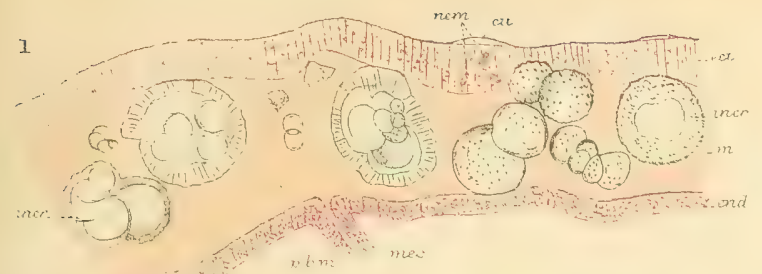

2

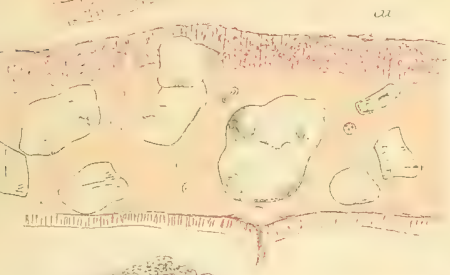

3

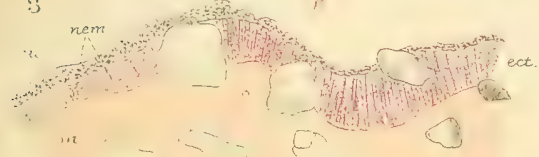

and

7

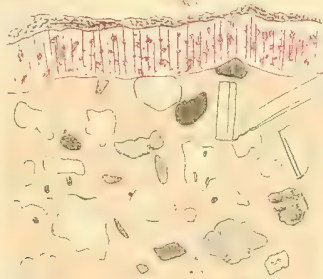

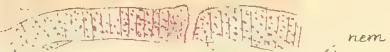

8

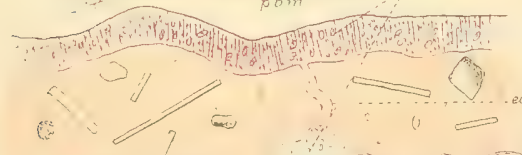

9

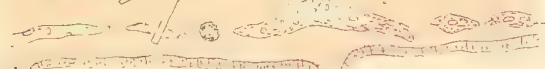

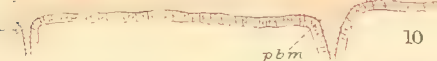

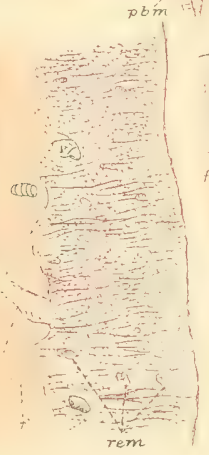

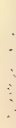

ection
5

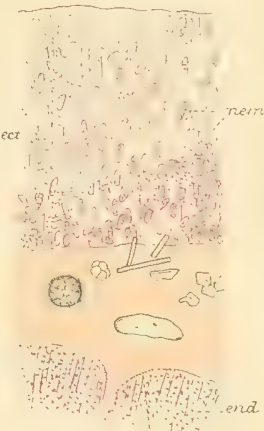

p.bim
6

Plate LIX.

41

W $-20 \mathrm{O} \quad \mathrm{v}$

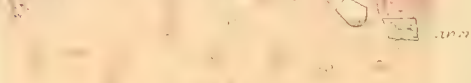

$+\quad ; \quad ;$

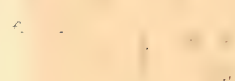

4.

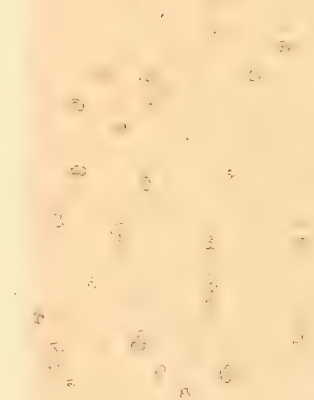

द.

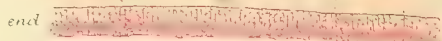
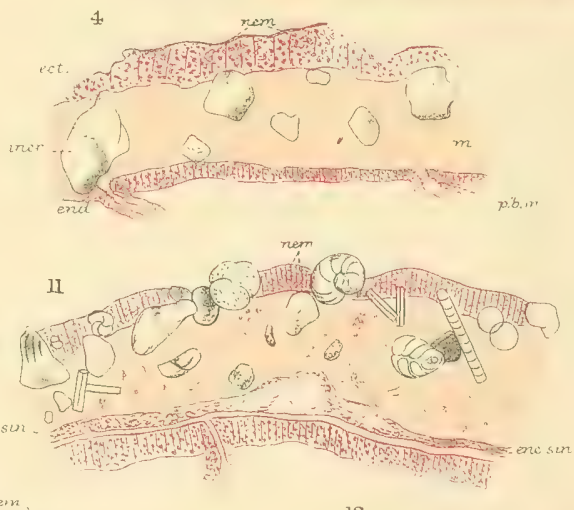

12
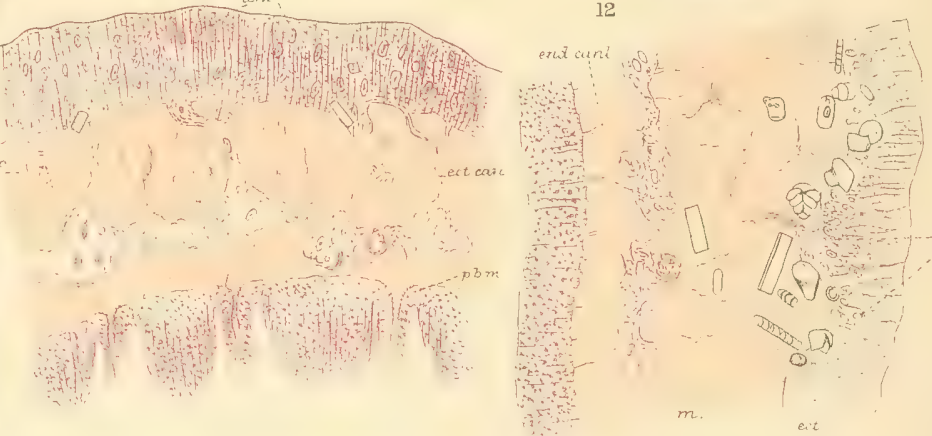

ene sin 

EXPLANATION OF PLATE LX. 


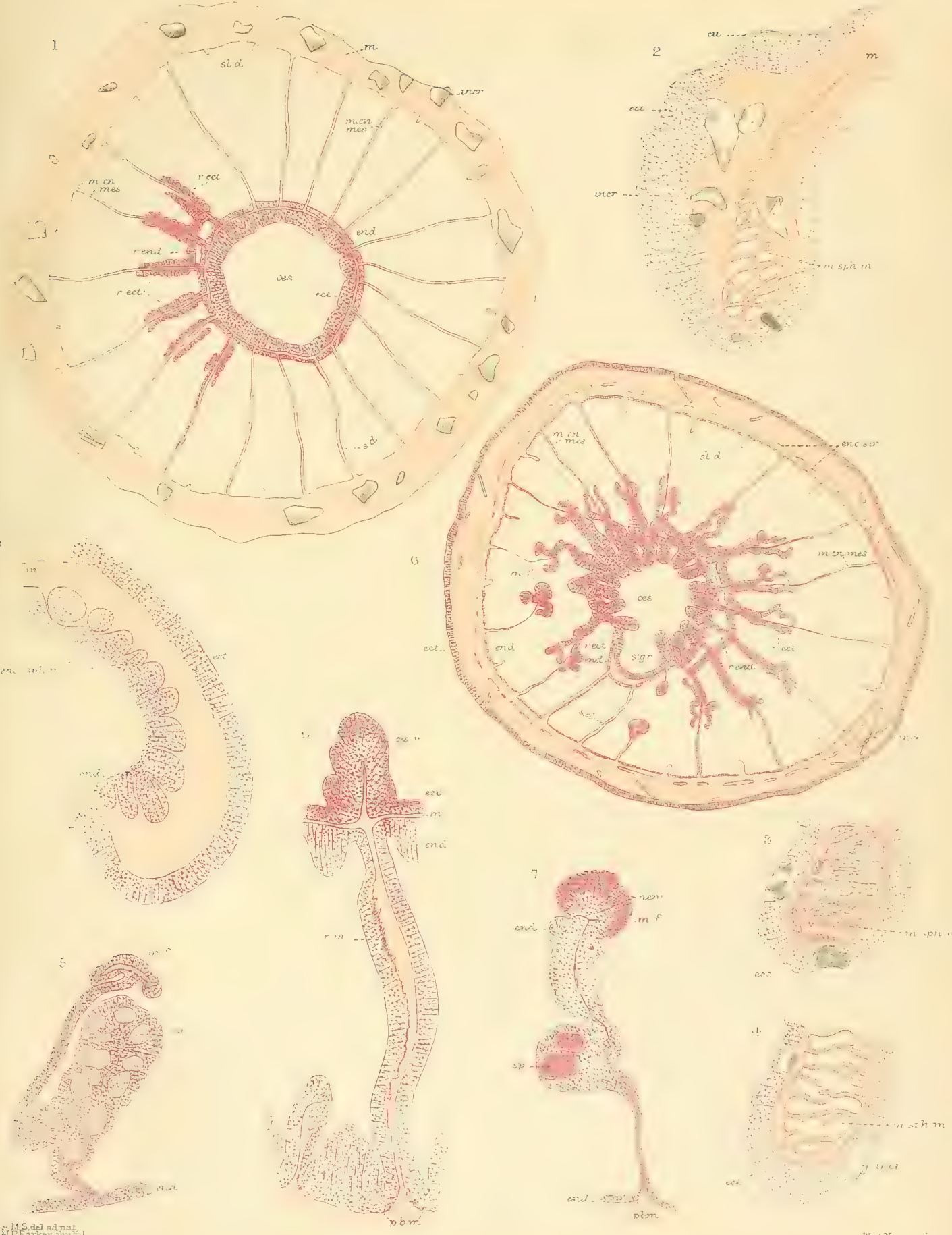






\section{TRANSACTIONS (NEW SERIES).}

\section{VOLUME I.}

Parts 1-25.-November, 1877, to September, 1883. (Part 25 contains Title-page to Volume.)

\section{VOLUME II.}

Parts 1-2.-August, 1879, to April, 1882. (Part 2 contains Title-page to Volume.)

\section{VOLUME III.}

Parts 1-14.-September, 1883, to November, 1887. (Part 14 contains Title-page and Contents to Volume, also Cancel Page to Part 13.)

PART

\section{VOLUME IV.}

1. On Fossil-Fish Remains from the Tertiary and Cretaceo-tertiary Formations of New Zealand. By James W. Davis, F.G.S., F.L.S., \&c. Plates I. to VII. (April, 1888.) $4 s .6 d$.

2. A Monograph of the Marine and Freshwater Ostracoda of the North Atlantic and of NorthWestern Europe. Section I. Podocopa. By George Stewardson Brady, M.D., F.r.s., F.L.S., and the Rev. Alfred M. Norman, M.A., D.C.L., F.L.s. Plates VIII. to XXIII. (March, 1889.) 1'́r. v́d.

3. Observations of the Planet Jupiter, made with the Reflector of Three Feet Aperture, at Birr Castle Observatory, Parsonstown. By Отто Boeddicker, PH.D. Plates XXIV. to XXX. (March, 1889.) 3s.

4. A New Determination of the Latitude of Dunsink Observatory. By Arthur A. Rambaut. (March, 1889.) 1s.

5. A Revision of the British Actiniæ. Part I. By Alfred C. Haddon, M.A. (Cantab.), M.R.I.A., Professor of Zoology, Royal College of Science, Dublin. Plates XXXI. to XXXVII. (June, 1889.) 5s.

6. On the Fossil Fish of the Cretaceous Formations of Scandinavia. By James W. Davis, F.G.S., F.L.s., F.S.A., \&e. Plates XXXVIII. to XLVI. (November, 1890.) 7s.

7. Survey of Fishing Grounds, West Coast of Ireland, 1890. I.-On the Eggs and Larvæ of Teleosteans. By Ernest W. L. Holt, St. Andrew's Marine Laboratory. Plates XLVII. to LII. (February, 1891.) 4s. 6d.

8. The Construction of Telescopic Object-Glasses for the International Photographic Survey of the Heavens. By Sir Howard Grubb, M.A.I., F.r.s., Hon. See., Royal Dublin Society. (June, 1891.) 1s.

9. Lunar Radiant Heat, Measured at Birr Castle Observatory, during the Total Eclipse of January 28, 1888. By Отто Boeddicker, PH.D. With an Introduction by The Earl of Rosse, K.P., LL.D., F.R.S., \&c., President of the Royal Dublin Society. Plates LIII. to LV. (July, 1891.) 2s.

10. The Slugs of Ireland. By R. F. Scharff, PH.D., B.sc., Keeper of the Natural History Museum, Dublin. Plates LVI., LVII. (July, 1891.) 3s.

11. On the Cause of Double Lines and of Equidistant Satellites in the Spectra of Gases. By George Johnstone Stoney, M.A., D.sc., F.R.s., Vice-President, Royal Dublin Society. (July, 1891.) 2s.

12. A Revision of the British Actiniæ. Part II. : The Zoantheæ. By Alfred C. Haddon, M.A. (Cantab.), M.R.I.A., Professor of Zoology, Royal College of Science, Dublin; and Miss Alice M. Shackleton, B.A. Plates LVIII., LIX., LX. (November, 1891.) 3s. $6 d$. 

